\begin{tabular}{|c|c|c|}
\hline Received 30.11.2020 & \multirow{3}{*}{ Research Article } & \multirow{3}{*}{$\begin{array}{c}\text { JOTS } \\
5 / 1 \\
2021: 48-95\end{array}$} \\
\hline Accepted 24.12.2020 & & \\
\hline Published 10.01.2021 & & \\
\hline
\end{tabular}

\title{
Eski Türkçeden Çağdaş Türk Lehçelerine Çap- Fiili ve Türevleri
}

\author{
From Old Turkic to Turkic Languages Çap- and Its Derivatives
}

\author{
Cüneyt ÇETÍnKAYA ${ }^{*}$ \\ Kahramanmaraş Sütçü İmam University (Kahramanmaraş/Turkey) \\ E-mail: cuneytcetinkaya@hotmail.com
}

In this article, will focus on which is the root of some of the words used today in Turkish and other Turkic languages, and nevertheless we do not know more than the origin čap-and its some derivatives it is believed to derive from these actions. The origin of the word, its derivatives and meanings from the Old Turkic to the present, and the ways in which it continues to live in modern Turkish languages and Anatolian dialects have been researched and it has been tried to determine whether the root meaning is preserved in the stems we use.

Key Words: čap-, čapar, čavuš, historical and contemporary Turkic languages.

\footnotetext{
ORCID ID: 0000-0002-0049-1482.
} 


\section{ग(৫)}

\section{Giriş}

Eski Türkçede çok az örneği olan fakat Orta Türkçeden sonra çok yaygın kullanımlarla karşımıza çıkan çap- fiili ve türevleri, neredeyse bütün Türk lehçelerinde, bazen aslî şekliyle bazen de küçük ses değişiklikleriyle hâlâ yaşamaktadır. Bugün Türkiye Türkçesinde aslî fiil olarak çok tanımadığımız çapfiilinin kökeni ile ilgili bir tartışma söz konusu değildir. Neredeyse bütün Türkologlar fiilin sesten yansıma ${ }^{2}$ yoluyla türediği konusunda hemfikirdir. Zaten 'bir sıvıya ya da nispeten yumuşak bir yere vurunca çıkan ses' ortak anlamında buluşabilecek pek çok türevin ortaya çıkmış olması bunun bir kanıtı olarak gösterilebilir. Bu farklı türevlerin tarihî seyir içerisindeki kullanımlarına yazımızın ilerleyen bölümlerinde değineceğiz. Ancak köken söz konusu olduğunda akraba dilleri de göz önünde bulundurmanın faydalı olacağı görüşündeyiz.

S. A. Starostin, A. V. Dybo ve O. A. Mudrak'ın hazırladığı Altay Dillerinin Etimolojik Sözlüğü adlı eserde çap- fiili ile ilgili bilgiler *çāp'a maddesinde verilmiştir: *çāp'a ( -u, -i) ‘kesmek, vurmak'; Tunguz *çapka; Moğol *çapçi-; Türk *çap-; Kore *çak (Starostin et al., 2003: 416). Sözlükteki bu bilgilerden anlıyoruz ki çap sesi ve bu sesten türemiş olan çap- fiilinin varyantları -Japonca hariç- Altay dillerinde benzer anlamlarla kullanılmaktadır. Bu bilgi, kelimenin Altay dillerine atalarından kaldığını göstermektedir ki bu da kelimenin çok eski bir kullanıma sahip olduğu anlamına gelir. Hatta Macarca ve Fincede de benzer şekil ve anlamlarda yaşıyor olması (Doerfer, 1967: 15 [1039]), kelime ödünçlemesini gösterebileceği gibi Ural dilleri ve Altay dillerinin -her ne kadar tartışmalar sürse de- akrabalık göstergelerinden biri de olabilir.

Eski Anadolu Türkçesi sonuna kadar anlamı oldukça genişleyen (ArslanErol, 2014: 238) çap- fiili, her ne kadar çok eski bir kullanıma sahip olsa da fiil hakkındaki ilk bilgilere Kaşgarlı Mahmut'un sözlüğünde rastlıyoruz. DLT'de çapfiili ve türevleri 13 farklı örnekte geçmektedir:

Kayasandık, Türkiye Türkçesinde ölen Fiiller adlı çalışmasında çap- fiilini çeşitli anlamlarıyla birlikte Yazı Dilinde Ölen, Ağızlarda Farklı Anlamlarda Yaşayan Fiiller başlığı altında listelemiştir (2018: 117).

2 Söz konusu çap- fiili, Zülfikar tarafından 'birincil durumda yansımalı fiiller'e örnek olarak gösterilmiş (1995: 108) ve sözlük bölümünde de Türkiye Türkçesi ağızlarında ve DLT'de geçen türevleriyle birlikte verilmiştir (1995: 380-381). 


\section{0}

er suwda çapdl "adam suda yüzdü", ol atın çıbık birle çapdı "o, atını yavaşçana vurdu, çırpıştırdı", çomak tat boynın çapdı "Müslüman gavurun boynunu vurdu", er ewin çapdı “adam evini arı çamurla sıvadı" (Atalay, 1985: II/3).

anı̇ ewi çapıldı ${ }^{3}$ "Onun evi sıvandı" (Atalay, 1985: II/119).

er atın çapındı "Adam atını kamçıladı" (Atalay, 1985: II/149).

it kişige çapıttı "Köpek adama saldırdı", beg anı̀ boynın çapıttı "Bey onun boynunu vurdurdu" (Atalay, 1985: II/298).

bu it o kişige çapıtgan "Bu köpek insana çok saldırgandır", çapıtgan er "Cellat, boyun vuran" (Atalay, 1985: I/513).

ol suwda çapsadı “O, suda yüzmek istedi” (Atalay, 1985: III/284).

er kulın suwda çapturdı "Adam kölesini suda yüzdürdü”, ol anı boynın çapturdl "O, onun boynunu vurdurdu”, ol ewin çapturdı "O, evini özlü çamurla sıvattı” (Atalay, 1985: II/180).

$\mathrm{Bu}$ örnekleri dikkatle incelediğimizde fiilin kök veya gövdelerinin şu anlamlarda kullanıldıkları görülür:

çap- 'yüzmek; arı çamurla sıvamak; (Uygurca) vurmak'.

çapıl- 'ince, iyi, yumuşak çamurla sıvamak; (Uygurca) boynu vurulmak'.

çapın- 'kamçılamak; yüzmek'.

çapıt- 'saldırmak; (Uygurca) vurdurmak'.

çapıtgan 'çok saldıran'.

çapitgan er 'cellat, boyun vuran'.

çapsa- 'yüzmek istemek'.

çaptur- 'suda yüzdürmek; çamurla sıvatmak; (Uygurca) boyun vurdurmak' (Atalay, 1986: 135-136).

DLT'deki kullanımlarda da görülüyor ki fiilin temelde beş farklı anlamı vardır: '1. yüzmek; 2. çamurla sıvamak; 3. (boyun) vurmak, kesmek; 4. kamçılamak; 5. saldırmak'. Beş farklı kullanımı da anlamsal açıdan değerlendirecek olursak aslında hepsinin bir şeye vurunca çıan çap ${ }^{5}$ sesiyle -

3 Kaşgarl, bu örnekten sonra "Bir adamin boynu vurulursa yine böyle denir. Uygurca" notunu düşmüştür (Atalay, 1985: II/119).

4 Kaşgarlı, bu örnekten sonra "er suwda çapdı bu anlamda çapındı dahi denir" notunu düşmüştür (Atalay, 1985: II/149).

5 DLT'de bir yerde çap çap ikilemesi 'kamçı vurulurken çıkan ses' ve 'dudağın şapırdaması' anlamıyla geçmektedir. Ancak burada 'dudak şapırtısı' ile ilgili örnek verilirken 'kamçı sesi' ile ilgili örnek verilmemiştir (Atalay, 1985: I/318). 


\section{J(৫)}

bugün bizim şap ${ }^{6}$ dediğimiz sesle- ilişkili olduğu hemen anlaşılacaktır ${ }^{7}$. Suya vurunca çıkan ses 'yüzmek', çamuru bir yere vurunca çıkan ses 'sıvamak', bir ete kesici aletle vurunca çıkan ses 'kesmek', bir ete kamçıyla vurunca çıkan ses 'kamçılamak' anlamlarını kazanmış olmalıdır. Zira DLT'de 'kamçı, kamçı ucu' anlamında bir çawıg ( * *çabıg < *çapıg) kelimesi de iki yerde geçmektedir (Atalay, 1986: I/374, II/231). Bu beş anlam içinde 'saldırmak' anlamı çap- fiili açısından oldukça zordur. Ancak saldırmak 'akın etmek, koşmak' anlamlarında olabileceği ve kamçılama'nın da atları şahlandırmak veya koşturmak için yapıldığı düşünülürse pekâlâ 'saldırmak' anlamındaki çapıt- ettirgen fiilinin 'kamçılamak' anlamındaki çap-'tan türemesi mümkündür. Yani buradaki köpeğin saldırma'sını 'köpeğin bir insanın üzerine atılması hatta bir insanın üzerine koşması' şeklinde değerlendirmek daha uygun olacaktır. Zira yukarıdaki beş anlam içinde 'yüzmek' ve 'sıvamak' sonraki yıllarda sınırlı bir kullanımda kalacak ama 'kamçıyla veya kesici bir aletle vurmak’ anlamları daha da genişletilerek pek çok yeni fiilin ve ismin ortaya çıkmasını sağlayacaktır.

\section{Etimoloji Sözlüklerinde çap- Fiili}

Vambery, Etymologisches Wörterbuch der Turko-Tatarischen Sprachen'de çapfiili ve türevleri ile ilgili düşüncelerini şu şekilde açıklamıştır:

çag. çapmak = vurmak, dövmek, acele etmek, koşmak.

çapuk = aceleyle, çabuk, hızlı.

çapaul, çapau = baskın, soygun.

çapku = biçak, çapa.

çapki = vuruş, kesme.

6 Bugün Türkiye Türkçesinde 'vurmak' anlamında kullandığımız şap sesinden türeme şaplat- fiili bununla ilgili olsa gerektir. (TS, 2005: 1848-1849) Zira DLT'de de bir yerde şap şap ikilemesi 'vurmada çıkan ses' anlamıyla; bir yerde de 'yemekte ağızda çıkan şapırtı' anlamıyla geçmektedir: anı şap şap boyunladl "Onun şap şap boynuna vurdu" (Atalay, 1985: III/145); ol kagunug şap şap yedi "O kavunu şapur şupur yedi” (Atalay, 1985: III/146)

Zülfikar, çap > cap ve çip > cip kelimelerini "Sulu, batak olmayl; sıvı maddeler içinde oluşturulan hareketleri anlatır” şeklinde tanımlamıştır (1995: 76). Kavramlar dizini bölümünde ise çab, çap, çalp, çıb, çıp, çip, çulp kelimelerinin hepsinin "Sivı vb. maddeler içinde kendi kendine ya da elle, ayakla oluşturulan hareketleri, bu tarzda çabalamayı anlatır” tanımlamasıyla açıklamıştır (1995: 193). Aynı yerde şab, şap kelimeleri için de "Sıvıların dökülü̈şünü, yağışını, akışını ya da su içinde oluşturulan bir hareketin çıkardığı sesleri anlatır" yorumunu yapmıştır (1995: 261). 


\section{ग(৫)}

çap = dörtnala.

çapkun = çatışmacl, çatışma, yağmacı.

çaukun = yüze çarpan kar veya yağmur.

çaplamak = etrafı dağıtmak, huzursuzluk vermek.

çapkulamak = takılmak, etrafta dolaşmak.

çapkulin = k1lıç dövüşü.

az. çapar = hızlı sürücü, posta, kurye.

osm. çapmak (yukarıdaki gibi).

çapa = çapa, kazma.

çabuk = hızlı.

çabalamak = çabalamak, uğraşmak (krş. çag. çapalamak).

çapkın = haydut (krş. çag. çapkun).

çuv. çop $^{8}=$ koşmak; çoptar = sürüklenmek, avlanmak.

jak. çäpçäki ${ }^{9}$ hafif, çevik, pervasız (krş. osm. çapkın).

Yumuşak vokallerle, yani e ile başlayan bu kök hece hala çag.'da tanınabilir. çevik ve çeber = çevik, aceleci; ö ile de şu kelimelerde: çöp = gübre, atık, çuv. sjüp = gübre; çag. çöpü = cüce, burada her yerde doğranmış, ezilmiş, yani 'doğrayıcı' temel kavramı temsil edilir. (1878: 143)

Ayrıca Vambery, 'gözcü (aslen bir kraliyet emrinin habercisi)' anlamlarını verdiği Osmanlı Türkçesindeki çavuş, çauş kelimelerini çav 'bağırma, çağırma, ses, şöhret' maddesinin altında zikretmiştir (1878:130). Tarihte ve günümüzde askerî bir rütbe olarak kullanılan çavuş kelimesinin Eski Türkçede çabış şeklinde kullanıldı̆̆g düşünülürse Vambery'nin iddia ettiği gibi çavuş kelimesinin kökünün çav olmasının akla yatkın olmadığı söylenebilir.

Doerfer, çavuş kelimesine 'korucu, muhafız, kervan rehberi' anlamlarını vermiş (1967: 35 [1055]); kelimenin şekil ve anlam değiştirerek Farsça, Arapça, Kafkas dilleri, Balkan dilleri, Lehçe, Macarca, Ukraynaca ve Slovakçaya geçtiğini belirtmiştir (1967: 37-38 [1055]). Doerfer'in özellikle Lehçe ve Macarca'da kelimenin 'kurye, ulak, postacı' gibi anlamlarda kullanıldığını belirtmiş olması

8 Vambery'nin Çuvaş Türkçesinde çop şeklinde verdiği kullanımı biz güncel sözlüklerde çup- şeklinde tespit ettik (Bayram, 2019: 907).

9 Vambery'nin Yakut Türkçesindeki çäpçäki kelimesine verdiği 'çevik' ve 'pervasız' anlamlarını biz sözlükte bulamadık (Sleptsov, 1972: 516). Ayrıca çap- fiilinin Yakut Türkçesinde kelime başı /ç/ > /s/ değişimi ile sabaa şeklinde kullanıldığını tespit ettik (Sleptsov, 1972: 307). 


\section{I(G)}

(1967: 38/1055) bizim için dikkat çekicidir. Zira bu anlam -yazının devamında bahsedeceğimiz üzere- tarihî ve çağdaş Türk lehçelerinin hemen hepsinde karşımıza çıkacak bir yayılım göstermiştir. Zaten Doerfer, maddenin sonunda kelimenin Grekçe ya da Farsça olduğunu söyleyenlere katılmadığını belirtirken Vambery'e ve onun gibi düşünenlere de katılmadığını, kelimenin çav kökünden türemiş olamayacağını söyler (1967: 38 [1055]). Ancak kelimenin hangi kökten türemiş olabileceği ile ilgili bir fikir de beyan etmemiştir ${ }^{10}$.

Söz konusu çavuş kelimesi ile ilgili en açıklayıcı yorumu H. Şirin yapmıştır. Şirin'e göre çabış unvanı, Türkçe çap- 'vurmak' fiilinin isim gövdesidir. Bu tezi, yargan ve kapgan unvanlarının yar- ve kap- fiillerinden türemiş olması desteklemektedir. 'Vurmak', ‘yarmak', ‘kapmak, kapıp almak' anlamlı fiillerden türeyen isimlerin, savaşçıl niteliklerin çok önemli olduğu eski toplumlarda unvan veya özel ad haline gelmesi tabiidir (2006: 226). Kelimeyi ad haline getiren \{-1ş\} ekinin türettiği sözler, çoğunlukla kavram düzeyindedir. Bazen, fiil kökü geçişliyse fiilin nesnesini, geçişsizse failini gösterir. Bu sözlük birimleri hem soyut hem de somut kavramları kapsayabilir: kargış 'lanet, beddua; lanetlenmiş kişi'. \{-ş\} ile yapılan isimler, hipotetik olarak geçişli fiillerin kılıcısını belirtirler. DLT'deki Atış, Sünüş, Tokış ve Utuş özel adları at- 'atmak, vurmak', süy- 'mücadele etmek, savaşmak', tokl- 'vurmak', ut- 'zafer kazanmak' fiillerinden türemiştir (Şirin-User, 2006: 226). Bu verilerden de anlaşılacağı üzere, fiillerden \{-ş\} ile türetilen kavram düzlemindeki sözler, özel adlara kaynak oluşturabilmektedir. DLT'de kayıtlı özel adların yapısındaki fiil köklerinin anlamlarına bakıldığında 'vurmak; atmak; vuruşmak; zafer elde etmek' gibi savaşçıl hareketleri karşıladıkları gözlenir. Bu bağlamda, çabış unvanının savaşçıl birkaç hareketin adı olan çap- fiilinin \{-ş\} ile türetilmiş gövdesi olduğu rahatlıkla söylenebilir (Şirin-User, 2006: 227).

Doerfer, çapar 'postacı' (1967: 12 [1033]), çapav 'baskın, yağma' (1967: 13 [1034]), çaphun 'hızlı, beklenmeyen saldırı' (1967: 13 [1036]), çapqunçı 'hafif donanımlı hızlı asker, baskına katılmış kişi' (1967: 14 [1037]), çapıdan 'baskın yapmak, yağmalamak' (1967: 15 [1039]), çapavul 'baskın, bir baskın sonucu ani saldırı' (1967: 48 [1063]), çapqulaş 'kavga, meydan kavgası' (1967: 52 [1065])

10 Doerfer, kelimeyi çap- köküne bağlamadığı için aşağıda onun kitabından yaptığımız madde başı örneklerinin arasına çavuş kelimesini almamayı uygun gördük. 


\section{J(e)}

maddelerinde bu kelimelerin kökünün çap- fiili olduğunu belirtmiş ve anlamını 'dörtnala saldırmak' olarak değerlenmiştir.

Doerfer, çap- fiili ile ilgili daha geniş bilgiyi ise çapıdan 'baskın yapmak, yağmalamak' maddesinde (1967: 15 [1039]) vermiştir:

Cf. DEDE 336 çap- 'son hızda koşmak, saldırmak', PC 272 جإِمق 'acele ile koşmak, koşmak', R III 1916 çap- Uygur ve Çağatay da dâhil pek çok lehçede 'saldırarak vurmak; hızla gitmek, dörtnala koşmak', RÄSÄNEN 1949, 181 tü. lehçe formu (çap- şap- sap- sop-), ÖZBB 526 ça ${ }^{\circ}$ p- 'koşmak; dörtnala gitmek; kesmek', KIR 385 şabu (mastar fiil olarak şap-) 'baskın yapmak' (Nogay ve Kırgız dahil). ABAEV 306 Oset dilinde cævyn:cavd / cævun:cavd 'dövmek, vurmak' anlamlarıyla yaşar. İranî olan ve olmayan pek çok dilde de paralellik gösterir: (Sogd. çb- 'çalmak', Fars çâpîdan 'çalmak', Pamir ağızları caf- 'çalmak', Mo. çab'dövmek, vurmak', Udmurt ve Suriye'de çap 'çırpıc1, döven, yayık' vb.). GOMBOCZ-MELíCH 850-9 Macar. csap- 'vurmak, dövmek', Fince ve Altay dillerinde de aynı.

Nadelyaev ve ekibinin hazırladığı Drevnetyurkskiy Slovar'da çap- fiili ve türevleri DLT'den alınan örneklerle açıklanmıştır:

ol atnı çııık birle çapdı "O ata çubukla vurdu".

er ewin çapdı "Adam evini arı çamurla sıvadı".

er suvda çapdl "Adam suda yüzdü".

anı̇ ewi çapıldı "Onun evi sıvandı".

er atın çapındı "Adam atını kamçıladı".

it kişige çapıttı "Köpek adama saldırdı".

çapitgan er 'cellat, boyun vuran'.

ol suwda çapsadı "O, suda yüzmek istedi".

ol ewin çapturdl "O, evini özlü çamurla sıvattı”.

er kulın suwda çapturdı "Adam kölesini suda yüzdürdü” (1969: 139).

Sadece 'boyun vurmak' anlamındaki çap- fiili, farklı olarak bojun maddesinin devamında verilmiştir: çomak tat boynın çapdl "Müslüman gavurun boynunu vurdu", beg anì boynin çapittı "Bey onun boynunu vurdurdu" (Nadelyaev et. al., 1969: 111). Maddeler arasında bulunan çap- fiillerinden dördüncüsünün tap- 'bulmak' anlamında verildiği ve şöyle örneklendirildiği görülmektedir: soy colda bir altun jani çapdılar "sonra yolda bir altın yay buldular" (Nadelyaev et. al., 1969: 139). Buradaki tap- > çap- değişimi şimdiye kadar hiçbir lehçede görülmeyen bir değişikliktir ve müstensihin bu söz başındaki /t/'yi /ç/ ile karıştırmış olduğu zannedilmektedir (Bang \& Arat, 1936: 42 [136]) ve yine çap- 
fiilinin altıncı ve çaptur- fiilinin üçüncü maddesinin anlam olarak 'yapmak' ve 'yaptırmak' olduğu ve bu fiillerin cap- ve captur- maddelerinde tekrarlandığ1 görülmektedir (Nadelyaev et. al., 1969: 641). Yani yanlış yazılmış olan çap- (< tap-) 'bulmak' fiili ile 'yapmak' anlamındaki çap- (cap-) fiili, taşıdıkları anlamlar açısından bizim çalışmamızın konusu olan çap- fiilinden farklıdırlar.

Räsänen, Versuch Eines Etymologischen Wörterbuchs der Türksprachen'de çapfiilini 'vurmak, kil ile sıvamak (evi)' anlamlarıyla açıklamış. Ancak örnek cümle vermemiştir. Bununla birlikte çapuk 'çabuk, hızlı' maddesinde bu kelimenin çap'vurmak' fiilinden türemiş olabileceğini yanına soru işareti (çap-?) koyarak iddia etmiştir (1969: 99).

Clauson, çap- fiili ve bu fiilden türeyen fiilleri sözlügünde Kaşgarlı'dan aldığı örneklerle açıklamış daha sonra da Çağatay, Kıpçak ve Osmanlı sahalarındaki kullanımlarına değinmiştir:

Hem geçişli hem de geçişsiz pek çok anlamla ses taklidi bir fiil (krş. çap), gürültülü hareketi tam olarak tanımlıyormuş gibi görünen kelimeler arasındaki tek anlam bağı. Bazı fonetik değişiklikler ve pek çok farklı anlamla bütün modern lehçelerde yaşıyor. Hak. XI er suvda çapdı "Adam suda yüzdü" ve ol atnı çıblk birle çapdı "O atı çubukla dörtnala sürdü (şaha kaldırdl)"; Uyğg. çomak tat boynın çapdı "Müslüman inanmayanların boynunu vurdu (kesti)" Çă̆. XV (1) segirt- 'koşmak', (2) baş kes- Kıp. XIV vurmak, tek bir darbe ile kesmek XV sürmek, çiftlik hayvanı sürme anlamında Osm. XIV (1) saldırmak, baskın XIV ve XV daha sonra tek tük (2) dörtnala gitmek, daha yaygın olarak acele etmek XV ve ilerisi (3) atı dörtnala sürmek'; çapıt-: it kişige çapıttı, beg anıı boynın çapıttı, çaptur-: er kulın suwda çapturdı, ol anıı boynin çapturdı, ol ewin çapturdı (1972: 394-395).

çapıl-: anıı ewi çapıldl; çapın-: er atın çapındı; çapsa-: er kulın suwda çapturdı (1972: 397-399).

Ayrıca Clauson, çapğut 'çapit' maddesinde bu kelimenin anlamsal bağlantının uzak olmasına rağmen (1972: 396) sonradan başka bir anlam taşımaya başladığını düşünerek (1966: 27) çap- fiilinden türemiş olabileceğini belirtmiştir.

Tietze, sözlüğündeki çap- I maddesinde 'vurmak; (atı) vurarak koşturmak; koşmak, ivmek' anlamları ile tanımladığı fiili çap- II maddesinde 'çapa ile toprağı kabartmak' şeklinde tanımlamış ve çap- II'nin çapala- fiilindeki \{-AlA-\} genişlemesinin çıkarılmasıyla oluştuğunu belirtmiştir. Ve bir alt maddede bulunan çapa- I maddesini 'toprağı kabartmak için kullanılan alet' anlamıyla tanımlarken bu aletin çap- fiili ile ilişkisine değinmemiş, kelimenin İtalyanca zappa kelimesinden geldiğini iddia etmiştir (2002: 474). Bununla birlikte Tietze, 


\section{J(৫)}

çapar 'haberci, posta tatarı', çapavul 'düşmak arazisini talan eden cenkçi, akıncı', çapgın 'hızlı koşan (at)', çapın- 'atılmak, saldırmak, hızlı koşmak', çapkın (< çapgin) '1. koşan, koşucu; 2. çapkın adam' (2002: 475), çapuk/çapık- II 'alkış', çapul 'yağma, talan' (2002: 476) maddelerindeki kelimelerin kökü olarak çap- fiilini göstermiştir. Ayrıca çapuk > çabük > çapük şeklinde geliştiğini düşündüğü çapük 'tez, hızlı hareket eden' maddesinde Räsänen'in çapuk kelimenin kökü olarak çap- fiilini tahmin ettiğini belirtmiş, ancak çabük 'çevik, atik, becerikli' maddesinde kelimenin Farsça çâbuk’tan değiştiğini iddia etmiştir (2002: 461).

Tietze, çap- maddesinde yukarıdaki bilgileri verirken çarp- maddesinde de "1 'vurmak < Tk. dillerinde yalnı Oğuz grubunda mevcut olan fiil ET. çap- filinin bir gelişmesi görünüyor." açıklamasını yaptıktan sonra kert- < ET. ket-, sark < ET. *sak-, serp-<ET. sep- örneklerinin çarp < ET. çap- şekliyle benzer olduğuna değinmiştir. ${ }^{11}$ Tietze bununla birlikte aynı maddede çarp-fiilinin argoda 'kapmak, çalıp kaçmak' anlamında kullanıldığını da belirtmiştir (2002: 478). Bugün Türkiye Türkçesinde de çarp- fiilinin 'Hızla değmek, vurmak; el çabukluğu ile çalmak; zorla ele geçirmek' (TS, 2005: 398) gibi anlamlarının var olduğunu göz önünde bulundurursak günümüzde çap- fiilinin asli fiil olarak kullanılmıyor olmasını bu fiilin yerini / $r$ türemesiyle birlikte çarp- ${ }^{12}$ fiiline bıraktığını söyleyebiliriz.

Gülensoy, çap- maddesini '(atı) koşturmak; akın etmek, koşmak' anlamlarıyla açıklamıştır. Divanü Lugati't-Türk ve Kutadgu Bilig'de 'yüzmek' anlamıyla da kullanıldığını belirtmiştir (2007: 219). Sonraki maddelerde geçen çapak² 'eti tatsız, kılçıklı, iri pullu, yassı bir tatlı su balığı', çapar 'postacı', çapavul '(eski) akıncı, 1lgarcı', çapı 13 'güveç, toprak tencere' (2007: 219), çapık/ç̧epik 'alkış,

11 DLT'de Kaşgarlı da berk sözcüğünün aslının bek olduğunu, bu sözcükteki /r/ sesinin sonradan türediğini belirtmiştir (Atalay, 1985: I/349). Buran, bu olayı şu örnekle açıklamıştır: "Örneğin partla/partda- (< patla-) sözcüğünde, a ünlüsünden $t$ ünsüzüne geçerken, ağız hareketleri ve boğumlanma noktaları arasında önemli bir boşluk söz konusudur. Bir dudak ünsüzü olan $p$ ile kapanan ağız boşluğu ve dudaklar, a ünlüsüyle açık ve geniş bir hal alır. Ağız tam bu durumdayken $t$ ünsüzünün boğumlanabilmesi için tekrar bir kapanmaya doğru hareket etmesi ve dilin diş etlerine değerek bir kapantı oluşturması gerekir. Dil bu bölgeye doğru hareket ederken damaklara yaklaştığı noktada titreşir ve $r$ sesini meydana getirir. Böylece iki ses arasindaki mesafe ve boşluk da kapanmış olur." (2013: 189)

12 Sözcük Anadolu sahası metinlerinde XIV. yüzyıldan itibaren inorganik bir /r/türemesi yaşayarak çapve çarp- şeklinde karşımıza çıkar (Çetin, 2019: 383).

13 Gülensoy, çapı 'güveç, toprak tencere' maddesinin devamında çepin 'küçük çapa' kelimesinin de çapkökünden gelmiş olabileceğini Kırgız Türkçesindeki ketmen çap- 'toprak kazmak' anlamını dayanak göstererek iddia etmiştir (2007: 220). Ancak Kırgız Türkçesinde ketmen kelimesinin [Uygur Türkçesi 


\section{ग(৫)}

el çırpma' (2007: 232), çapış- 'birbirini dövmek, savaşmak', çapkın '1. oynak; 2. hırsız', çapul 'yağmalamak', çaput 'paçavra' (2007: 220), çaba 'gayret, çaba', çabuk 'acele, çabuk', çabucak/çabucacık 'hızla, vakit geçirmeden' (2007: 209) kelimelerinin hepsinin kökeni olarak çap- fiilini göstermiştir.

Ayrıca Gülensoy, yukarıda adı geçen çapar ( çapan) ve çapavul kelimelerinin Türkçeden Farsçaya geçmiş kelimeler arasında gösterirken (2012: 144-145) çarpmaddesinde fiile 'çarpmak, vurmak' anlamını vermiş ve Tietze'den aldığı örneklerle (kert-< ET. ket-, sark < ET. *sak-, serp- < ET. sep-) fiilin çap- fiilinden /r/ türemesi ile oluştuğunu savunmuştur (2007: 221).

Eren, Türk Dilinin Etimolojik Sözlüğü’nde çap- fiilini kök fiil olarak bir sözlük maddesi yapmamıştır. Ancak çabuk '1. alışılandan daha kısa bir zamanda, tez; 2. hızlı' maddesinde bu kelimeyi Räsänen'in soru işaretli (?) bir çap- köküne dayandırdığını belirtmiştir (1999: 75). Ayrıca çapak 'eti tatsız, kılçıklı, iri pullu, yassı bir tatlı su balığı (abramis brama)' maddesinde bu kelimenin de köken olarak çap- fiiline bağlanabileceğini iddia etmiştir (1999: 79). Bundan başka çaput 'eskimiş bez parçası, paçavra' maddesinde bu kelimeyle ilgili olarak 'Clauson'a göre bu kelime çap- kökünden -gut ekiyle kurulmuştur.' notunu düşmüştür (1999: 80).

\section{Tarihi Lehçe Sözlüklerinde ve Metinlerde çap- Fiili}

Yazımızın bu bölümünde çap- fiili ve türevlerinin önce tarihi dönemlerin sözlüklerinde nasıl yer aldığını sonra da o tarihi dönemdeki metinlerde ne şekillerde ve anlamlarda kullanıldığını göstermeye çalışacağız.

\subsection{Uygur Türkçesinde çap- Fiili:}

Yazımızın başında çap- fiili ile ilgili ilk bilgilere DLT'de rastladığımızı belirtmiştik. Ahmet Caferoğlu'nun hazırladığı Eski Uygur Türkçesi Sözlüğü'nde de çap- fiili ve türevlerine rastlanmamıştır (Caferoğlu, 1968). Ancak sözlük

döneminden beri] 'bel, kazma' (Yuhadin, 1998: 445) anlamında olduğunu göz önünde bulundurursak çap- fiilinin anlamının da 'vurmak' ile ilgili olduğu açıktır. Ama bu çepin kelimesinin kökünün çap- fiili olamayacağı anlamına gelmez, sadece Kırgız Türkçesindeki anlamın zorlama olduğu kanaatindeyiz. 


\section{J(৫)}

haricindeki metinlere baktığımızda fiilin ve türevlerinin Eski Uygur Türkçesinde de kullanıldığı görülmektedir ${ }^{14}$ :

örü kodı yerlärig kizä oy kötki / yerlärig tüzä sapan tutup savilu / kararu kurıp tarıyu / ketmän çapıp kävilü olurmadın... (Zieme, 1975: 113) 'Yukarı aşağı tarlayı dolaşıp çukuru, yükseği (bir hizaya getirip) toprağı düzleyerek sabanı tutup eğilip son derece kederlenip zayıflayıp (?) ekerek kazmayı vurup kuvvetsizleşip oturmaksızın ...' (Ayazlı, 2016: 515); çapça birlän ködürüp salmışta / ç(a)rlayu qumlayu qudulsun / çarın käyäsin käsäkin / çapıp kıdıgqa üntürsün (Molnar \& Zieme, 1989: 143) '(Mahsül) dirgenle yukarı kaldırıp bıraktıktan (sonra) çöp gibi kum gibi dökülsün. Çöpünü, yığınını, toprak parçasını vurup kenara çıkartsın.' (Ayazlı, 2016: 517).

Yukarıdaki örneklerde de görülüyor ki çap- fiili 'vurmak' anlamıla IX. yüzyılda da kullanılmaktadır. İkinci örnekte daha dikkat çekici bir şey vardır ki o da çapça 'dirgen, tırmık' kelimesidir. Metnin altında bulunan açıklama kısmindaki 48. maddede bu kelimenin çap- fiilinden türediği notu düşülmüştür ${ }^{15}$ (Molnar \& Zieme, 1989: 149).

Uygur metinleri arasında Tezcan'ın çalışması olan Das uiguische InsadiSutra'da da çap- fiilinin bir yerde kullanıldığı görülmektedir: talım kara kuş garudi taluy odrasinta çaparça tavranip tuǵdupuz tusidta taplançı̇ körkle maytriya "Yırtıcı kara kuş Garuda'nın ${ }^{16}$ deniz ortasında (avına) saldırışı gibi davranıp Tusita'da ${ }^{17}$ doğdunuz, harika ve güzel Maitreya." ${ }^{18}$ (1974: 70) Bu örnekte çap- fiilinin DLT'deki 'köpeğin saldırması' anlamına benzer bir anlamda kullanılmış olması fiilin hayvan saldırılarını anlatmak için de kullanıldığını göstermektedir.

14 DLT'de Kaşgarlı Mahmud'un çap- 'yüzmek; arı çamurla sıvamak; (Uygurca) vurmak', çapıl- 'ince, iyi, yumuşak çamurla sıvamak; (Uygurca) boynu vurulmak', çapıt- 'saldırmak; (Uygurca) vurdurmak', çaptur- 'suda yüzdürmek; çamurla sıvatmak; (Uygurca) boyun vurdurmak' (Atalay, 1986: 135-136) maddelerinde bazı anlamlara 'Uygurca' notunu düşmüş olması en azından X.-XI. yüzyıllarda bu fiilin Uygurcada da kullanılıyor olduğunu kanitlar.

15 Bu kelime çap̧̧a 'kürek' şeklinde günümüzde Yeni Uygur Türkçesinde de yaşamaktadır (Necip, 1995: 70).

16 Hindu ve Budist mitolojilerinde yarı kuş yarı insan olan efsanevi varlık.

17 Budizm'e göre gelecekte dünyaya gelecek olan son Buda Maitreya'nın dünyaya inmeden önceki yaşadığı göksel âlemdir.

18 Budizm'e göre gelecekte dünyaya gelecek olan son Buda'dır. 


\section{ग)}

\subsection{Karahanlı Türkçesinde çap- Fiili:}

Üşenmez'in hazırladığı Karahanlı Türkçesinin Sözlüğü'nde çap- fiili ve türevleri Divanü Lugati't-Türk ve Kutadgu Bilig'de geçtiği şekilleriyle yer almaktadır:

çap-I 'suda yüzmek'.

çap- II 'evi temiz çamurla sıvamak'.

çap- III 'yavaşça vurmak, çırpıştırmak'.

çap IV ‘birinin kafasını kesmek, boynunu vurmak’.

çapıl- 'evleri ince, yumuşak çamurla sıvamak'.

çapın-I 'suda yüzmek'.

çapın- II 'hayvanları kamçılamak'.

çapıt- 'çarpmak, vurmak, saldırmak'.

çapıtgan 'saldırgan'.

çapitgan er 'boyun vuran, cellat'.

çapsa- 'suda yüzmek istemek'.

çaptur- I 'yüzdürmek'.

çaptur- II 'insanın boynunu vurdurmak'.

çaptur- III 'evi özlü çamurla sıvatmak' (2010: 73).

DLT $^{19}$ ile aynı dönemde kaleme alınmış olan Kutadgu Bilig'de çap- fiili sadece bir defa 'yüzmek' anlamıyla geçmektedir: kayusı çapar kör kayu suv içer 'bak; kimisi yüzer, kimi su içer' (Arat, 1999: 24/73).

Karahanlı Türkçesi dönemi eserlerinden olan Atabetü'l Hakayık (Arat, 1992) ve Karahanl Türkçesinde Illk Kur'an Tercümesi (Rylands Nüshası)'nda (Ata, 2013) çapfiili örneklerine rastlanmamaktadır. Ancak yine Karahanlı Türkçesi eseri olmasına karşın XIV. yüzyılda istinsah edilmiş olan Karahanlı Türkçesi Satır Arası Kur'an Tercümesi (TIEM 73)'te kayıtlı nüshasında çap- fiilinin iki defa 'yüzmek' iki defa da 'vurmak' anlamında olmak üzere dört defa kullanıldığg görülmektedir (Ünlü, 2004: 406). Fakat ayetin Türkçe meali göz önünde bulundurulursa 'vurmak' (metin içindeki çeviride 'kamçılamak') anlamında kullanılan çap- fiili yerine

19 DLT'deki örnekler giriş bölümünde verildiği için burada tekrarlanmadı. 


\section{J(e)}

'vurulmak, kamçılanmak' anlamında edilgen çatılı çapıl- fiili olması gerektiğini düşünüyoruz:

kamuġ täzginmäk içindä çaparlar "Hepsi yörünge içinde yüzerler" (Ünlü, 2004: 42)

küllün fäläk içindä çapa täzginürlär "Hepsi göğün içinde yüzerek dönerler” (Ünlü, 2004: 142)

takı bolur taǵlar çap[ll]mış yün täg "Ve olur dağlar kamçılanmış yün gibi” (Ünlü, 2004: 247)

bolur tağlar çapı[l]mış yün täg “Olur dağlar kamçllanmış yün gibi” (Ünlü, 2004: 283)

Bunun yanında Borovkov'un XII.-XIII. yüzyıllara ait bir Kur'an tefsiri üzerine yaptığı çalışmasında da çap- fiilinin kullanıldığı görülmektedir. Borovkov'un çalıştığı bu eser, ülkemizde de Halil İbrahim Usta tarafından yüksek lisans tezi olarak sunulmuştur. Daha sonra ise Usta, Borovkov'un çalışmasını Ebulfez Amanoğlu ile birlikte Türkçeye aktarmıştır.

düldül tapa kamçı çapmış ermiş (Usta, 1989: 374) "Düldüle doğru kamçı vurmuş”, "düldül adlı ata kamçı ile vurmuş imiş" (Borovkov, 2002: 94).

kamug் tizginmek içinde çaparlar, kamuǵ felek içinde çapa tizginürler (Usta, 1989: 93) "Hepsi yörünge içinde gezinirler, hepsi göğün içinde gezinerek dönerler” (Borovkov, 2002: 94).

takı bolur taǵlar çapalmış ${ }^{20}$ yün kibi (Usta, 1989: 252) "Ve olur dağlar çalkanmış yün gibi” (Borovkov, 2002: 94)

çapturmadııız anıy üze atdın (Usta, 1989: 195) "Koşturmadınız onun üzerine atlardan (bir kısmını)" (Borovkov, 2002: 94)

Borovkov ve Usta'nın benzer ayetlerde çap- fiiline verdikleri anlamların Ünlü'nün verdiği anlamlardan farklı olduğu dikkati çekmektedir. Ünlü’nün çapfiiline 'yüzmek' anlamını verdiği ayetlerde Borovkov ve Usta'nın 'gezinmek' anlamını verdiği, Ünlü’nün 'kamçılanmak' anlamını verdiği ayetlerde ise Borovkov ve Usta'nın ‘çalkanmak, karışmak' anlamını verdiği görülmektedir.

Karahanlı Türkçesi döneminden sonra ise gerek Doğu Türkçesinde gerekse de Batı Türkçesinde yaygın bir kullanım kazanan çap- fiili Harezm, Kıpçak ve Eski Anadolu Türkçesi dönemlerinden sonra Çağatay ve Osmanlı Türkçesi dönemlerinde de varlığını sürdürmüştür.

20 Borovkov, bu kelimeyi çapalumuş şeklinde okumuştur. Ancak Usta "Kaynaklarda çapalu- şeklinde değil de, çapal-şeklindeki bir fiil kökü bulunmaktadır." diyerek okumayı düzeltmiştir. (2002: 348) Ancak biz sözlüklere baktığımızda çapal- şeklinde bir köke de rastlayamadık. Buradaki şekli Ünlü gibi (2004: 274, 283) bir istinsah hatası olduğunu düşünmekteyiz. 


\section{J(O)}

\subsection{Harezm Türkçesinde çap- Fiili:}

Suat Ünlü'nün hazırladığı Harezm-Altınordu Türkçesi Sözlüğü’nde çap- fiili ve türevleri Karahanlı Türkçesine yakın kullanımlara sahiptir:

çabük süvar 'ata iyi binen, binici'.

çap- I 'kesmek, parçalamak'.

çap- II '(el) vurmak, yüzmek'.

çap- III 'koşmak, (at) koşmak'.

çaptur- 'koşturmak, koşuşturmak'.

çapturt- 'parçalatmak, kestirmek'.

çapul-I 'dağılmak, atılmak'.

çawüksüvar 'iyi ata binen, binici’ (2012: 129, 131-132).

Nuri Yüce'nin dizinine göre Mukaddimet'ül Edeb'de çap- fiili iki yerde 'el vurmak', bir yerde '(at) koşmak', üç yerde de 'koşturmak' anlamlarıyla altı defa geçmektedir (2014: 110). Ancak örneklere bakıldığında bu altı kullanımın iki tanesi 'vurmak' geriye kalan dört tanesi de 'atı koşturmak' anlamındadır:

'vurmak'

çaptı iki eligini “íki elini (birbirine) vurdu” (Yüce, 2014: 47)

çaptı iki eligini, karstı "İki elini (birbirine) vurdu, el çırptı” (2014: 51)

'atı koşturmak'

dizgin kemişti at boyniğa çaptukda "Dizgin attı atın boynuna (at) koşturduğunda" (Yüce, 2014:

46)

çapturdı kölikni, yügürtti "Koşturdu bineğini, koşturdu”

çapturdı atını, yügürtti kölikni “Koşturdu atını, koşturdu bineğini” (2014: 39)

yügürtti, çapturdı atnı "koşturdu, koşturdu atını” (2014: 75)

Rabgûzî’nin Kıssasü'l Enbiyâ adlı eserinde çap- fiili 'kesmek, parçalamak' ve 'el vurmak' anlamlarıyla onbeş defa, çaptur- 'koşturmak, koşuşturmak' anlamıla bir defa, çapturt- 'parçalatmak, kestirmek' anlamıyla bir defa kullanılmıştır (Ata, 1997:156).

Demirci ve Karslı'nın hazırladığı dizine göre Kutb'un Husrev ü Şirin adlı eserinde çap- fiili 'kesmek' anlamıyla iki yerde, 'vurmak' anlamıla iki yerde; çapıt- '(kalp için) çarptırmak' anlamıyla bir yerde, çapul- 'harekete geçirilmek' anlamıla bir yerde geçmektedir (2014: 146). Ancak cümleler konu bütünlüğü 


\section{Je)}

açısından incelendiğinde çap- fiili 'kesmek' anlamıyla bir yerde, 'atı koşturmak' anlamıyla dört yerde, çapıt- '(kalp için) çarptırmak' anlamıyla bir yerde, çapul- 'at koşturulmak' anlamıyla bir yerde geçmektedir:

'kesmek'

tiledi çapsa boynın kayra yandı "Boynunu kesmek isteyerek geri döndü” (Hacıeminoğlu, 2000: 330)

'atı koşturmak'

geh ol şî̀în utar geh şâh perviz, geh ol gulgûn üzer geh çapsa şebdîz "Bazen Şirin yener bazen Şah üstün, bazen (Şirin'in atı) Gülgûn koparır koştuğu zaman (Şahın atı) Şebdîz” (Hacıeminoğlu, 2000: 261)

çapup bir sınalıy atlar tidiler "Koşturup atları bir sınayalım dediler" (Hacıeminoğlu, 2000: 226)

izin izleyü çaptılar soyınça "İzleyerek sonuna kadar (at) koşturdular" (Hacıeminoğlu, 2000: 226)

çapup tört yaru hiç tapmadı yârın "(Atını) koşturup dört yana yarini hiç bulamadı" (Hacıeminoğlu, 2000: 233)

'(kalp için) çarptırmak'

minim köglüm çapıtsun bu tilekim "Benim kalbimi çarptırsın bu dileğim" (Hacıeminoğlu, 2000: 420)

'at koşturulmak'

murad atı köyülçe son çapulġay "Murat (istek, arzu) atı gönlümüzce son kez koşturulacak" (Hacıeminoğlu, 2000: 281)

Nehcül Ferâdis'te de çap- fiili bir yerde geçmektedir. Aysu Ata hazırladığı dizinde fiilin 'koşmak' anlamında olduğunu belirtmiştir (1998:100). Ancak cümleyi incelediğimizde buradaki anlamın 'atı koşturmak' olduğu açıç̧a görülecektir: Abû Sufyân atına mündi, takı çapup Mekkeke kirdi. "Ebu Sufyan atına bindi ve (atını) koşturarak Mekke’ye girdi.” (Eckmann, 2014: 36).

\subsection{Kıpçak Türkçesinde çap- Fiili}

Recep Toparlı et al.'nn hazırladığı Kıpçak Türkçesi Sözlüğü’nde çap- fiili ve türevleri, Karahanlı Türkçesine yakın özellikler göstermekle birlikte yeni bazı şekiller ve anlamlar kazanmıştır:

çap- I'1. koşmak, 2. atılmak, hızlı hareket etmek, 3. sürmek, at koşturmak'

çap- II '1. vurmak, çarpmak, 2. kılıç vurmak, 3. bir defada hem vurmak hem kesmek'

çap- III 'yüzmek, suda çırpınmak' 


\section{J(e)}

çap-IV 'derisi soyulmak, yağır olmak'

çapdur- 'çaptırmak, koşturmak'

çapın-I 'birden hücum etmek'

çapın- II 'elin ayası ile vurmak'

çapla- 'boyna bir şey takmak'

çaplat- 'şaplak indirme, tokat vurma'

çapul- 'atılmak, vurulmak'

şap- 'çarpmak, vurmak', şapış ‘sürme’

şapla- 'taş yontmak'

şaplama 'şaplak, tokat'(2014: 46, 250).

Seyf-i Sarâyî̀nin Gülistan Tercümesi'nde de '(at) sürmek, koşturmak' anlamında (Karamanlığlu, 1989: 237) kullanılan çap- fiili, metinde iki kez kullanılmıştır:

süngü oynap at çapup köp türlü irdem körgüzüp... "Süngü kullanıp at koşturup çok türlü erdem gösterip..." (Karamanlığlu, 1989: 10)

atına minip vekâhat meydânında çapıp mana yigrip ayttı "Atına binip küstahlık meydanında (atını) koşturup bana hiddetlenip söyledi.” (Karamanlıŏlu, 1989: 154)

İrşâdü'l Mülûk ve's-Selâtîn adlı eserde çap- fiili 'atı koșturmak', çapul- fiili de 'vurulmak, dövülmek' anlamında birer kez kullanılmıştır:

atka minip, kerekse turup kllsun kerekse kölügi yürür irken kılsun, kerekse çapup yürür iken klsun "Ata binip, gerekirse durup (namaz) kılsın gerekirse bineği yürürken kılsın, gerekirse koşup giderken kılsın"

oş aniy kibi kaçan kim secde kılsa saman öze ya çapulmış mamuk öze, eger maplay tölenmese reva bolmas "isşte onun gibi ne zaman secde etse, saman üzerine veya dövülmüş pamuk üzerine, eğer alnı sabit değilse uygun olmaz" (Toparlı, 1992: 219, 248)

Munyetü'l Guzât adlı eserin atçllıkla ilgili olması sebebiyle çap- fiilinin çok sayıda kullanıldığı görülmektedir. Toplam 32 kullanımın bir tanesi 'koşmak', iki tanesi 'kesmek', on altı tanesi 'vurmak' ve on üç tanesi de 'atı koşturmak' anlamında kullanılmıştır.

'koşmak'

kaçan tilesey kim at üstünde ok atmaġa başlag̉ay-sen çapip bes bir yumşak ya algll "Ne zaman istersen at üstünde ok atmaya başlayacaksın, koşup yeterince yumuşak bir yay al" (Uğurlu, 1984: 83)

'kesmek' 


\section{0}

kılıçnin çapar yiri tutkasındın bir karış yir aşaġa turur "Kılıcın keskin tarafı kabzasından bir karış aşağıdadır" (Uğurlu, 1984: 72)

mundın bir karış mıkdârı çapıp "Bundan bir karış miktarı kesip" (Uğurlu, 1984: 76)

'vurmak'

saġındın kıllç birle çapgìl "Sağından kılıçla vur” (Uğurlu, 1984: 45)

kllı̧ birle çapġıl "K1lıçla vur” (Uğurlu, 1984: 56)

kaçan çapsa ilin titretgey "Ne zaman vursa elini titretecek"; sogra yine kayıra kılıçııı çaparken kınına sokmaknı ögrengeysen "Sonra yine tekrar kılııını vururken kınına sokmayı öğreneceksin"; atlarınıฤ tizlerini çapdılar yâ kulağını yâ kolını yâhûz özinin ayaklarını çaptılar takı kistiler "Atların dizlerini kılıçladılar, ya kulağını ya kolunu veya kendinin ayaklarına kılıçladılar ve kestiler" (Uğurlu, 1984: 73-75)

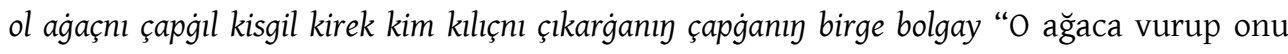
kesmen gerekir ki kılıcı çıkarmanla vurman bir olacak” (Uğurlu, 1984: 76)

ilin tamâm idmen alġay çapmag̉a ögrengey "Elin tamamen alışkanlık kazanacak, vurmayı öğrenecek" (Uğurlu, 1984: 76)

kaçan kılıç çapǵanda bileginni tışkaru-rak bura çapgill "Her kılıç vurduğunda bileğini dışarı doğru bükerek vur" (Uğurlu, 1984: 77)

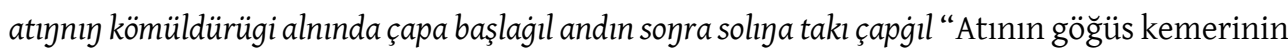
önünde vurmaya başla ondan sonra soluna da vur” (Uğurlu, 1984: 77)

her bir cihet-ge takı çapg்l ayag்ı alnında takı artında çapa başlag்ıl "Her bir tarafa da vur, ayağının önünde de arkasında da vurmaya başla” (Uğurlu, 1984: 78)

'atı koşturmak'

eger kıska bolsa atnı çapip tartġanda yıkılmakdan imin bolmas "Eğer kısa olursa atı koşturup çektiğinde yıkılmaktan emin olamazsın” (Uğurlu, 1984: 7)

her bir çapkanda habs kılıp turmaknı istimâl kılğıl "(Atını) her koşturduğunda bir yere kapatıp dinlendirme işini kullan" (Uğurlu, 1984: 13)

atıını tizlegil velâkin uzun çapmaġıl ol atlar kim anı̇ üzere süyü oynarlar uzun çapmak birle harâb bolurlar "Atını hızlandır fakat uzun süre koşturma; o atlar ki üzerinde savaşılır, uzun süre koşturunca harap olurlar" (Uğurlu, 1984: 13)

bes çapup yürür irken atı-nıり kuyruġındın tutup katığ tartġıl "Atını yeterince koşturup yürürken kuyruğundan tutup sıkıca çek" (Uğurlu, 1984: 42)

atınnı katıg çapmakdın habslegil "Atını hızlı koşturmadan önce bir yere kapat (dinlendir)" (Uğurlu, 1984: 47)

at birle çapup kilip “At ile koşturup gelip” (Uğurlu, 1984: 56)

atınnı meydâna sürüp katıg çapış birle ol halakanı süyü uçı birle andın alġı “Atını meydana sürüp hızla koşturarak o halkayı süngü ucu ile ondan al” (Uğurlu, 1984: 57) 
atınnı katığ çapı kilip bu oklarnı yünler aşaǵasında barçasın bir kibi çapǵ̀l "Atını hızla koşturup gelip bu okları tüylerin aşağısında hepsi birmişçesine vur” (Uğurlu, 1984: 76)

anı sag்ına alıp atınnı katıg் çapg்ıl ok atmaǵa çapar kibi "Onu sağına alıp atını hızla koştur, ok atmaya koşar gibi" (Uğurlu, 1984: 76)

atınnı çapıp kilip orta yirdin bu oklarnı sag்-g்a sol-g்a kise çıkǵıl "Otını koșturup orta yerden bu okları sağa sola keserek çı"” (Uğurlu, 1984: 77)

sol yanına üç bürcâs takı sag̉ yanına karşurak iki tikgil takı çapup kilip evvel sol yanındaġını atğıl soyra saǵ yanıydaġın atğıl "Sol yanına üç hedef sağ yanına tam karşısına iki hedef dik, atını koșturarak önce sol yanındakine sonra sağ yanındakine at” (Uğurlu, 1984: 84)

$\mathrm{Bu}$ dönemde yazılmış bazı eserlerde çap- fiilinin -bugünkü Kıpçak lehçelerinin karakteristik özelliği olarak görülen- kelime başı /ç/ > /ş/ değişimi yaşayarak şap- şeklini almaya başladığı görülmektedir. Öyle ki Kitâbü'l-İdrak Li Lisâni'l-Etrak'ta çap- 'bir defada hem vurmak hem kesmek', çapın- 'birden hücum etmek' gibi örnekler varken (Caferoğlu, 1931: 26) ondan yaklaşık yirmi üç sene sonra bu esere yapılan bir ilave olan El-İdrak Haşiyesi'nde şaplama 'şaplak, tokat' kelimesine yer verildiği görülmektedir ${ }^{21}$ (İzbudak, 1936: 44).

El-İdrak Haşiyesi ile aynı dönemin eseri olan Et-Tuhfetü'z-Zekiyye Fi'l-Lügati'tTürkiyye'de çap- fiilinin şap- 'çarpmak, bir aygıtla vurmak' şeklinde iki yerde, şapla- 'taş yontmak' şeklinde de bir yerde geçtiği görülmektedir. Ayrıca Atalay, şapla- fiilinin 'taş yontmak' anlamında olduğunu belirttiği dizinde bu anlamın yanına o dönemde bu fiilin 'tokat atmak' anlamının da olduğunu belirtmiştir (Atalay, 1945: 246). Böylece El-İdrak Haşiyesi'nde belirtilmemiş olsa da orada şaplama isminin şapla-fiilinden türediği anlaşllıyor.

Recep Toparlı'nın hazırladığı dizinde Ed-Dürretü'l-Mudiyye fi'l-Lügati'tTürkiyye'de çap- fiilinin şap- '[at] sürmek, çarpmak' şeklinde 3 yerde, şapış ‘sürme' şeklinde 1 yerde geçmektedir (Toparlı, 2018: 108). Ancak metne baktığımızda şapfiilinin 'çarpmak' anlamında kullanıldığına rast gelemedik:

bar, at min şap “Git, ata bin, sür” (Toparlı, 2018: 60)

şapış şap “At sür" (Toparlı, 2018: 60)

${ }^{21}$ Burada şunu belirtmek gerekir ki 'tokat' anlamı söz konusu olduğunda Türkiye Türkçesinde bulunan şaplak, şaplamak, şaplatmak (TS, 2005: 1849) kelimeleri de tokat ve tokatın çıkardığı sesle ilgilidir. Ancak bu örneklere bakarak Batı Türkçesinde de /ç/> /s / değişimi vardır demek doğru olmaz kanaatindeyiz. Zaten aynı dönemin ve aynı sahanın eserleri olan ETZ ve EDM eserlerinde çap- fiilinden şap-fiiline geçiş açıkça görülmektedir. 


\section{)}

men at mindim şaptım (şaptum) “At bindim, sürdüm” (Toparl, 2018: 60)

\section{5. Çağatay Türkçesinde çap- Fiili:}

Çağatay Türkçesine gelindiğinde çap- fiili türevleriyle birlikte anlam ağını oldukça genişletmiştir. Suat Ünlü’nün hazırladığı Çağatay Türkçesi Sözlüğ̈̈’nde çap- fiili ve türevleri şu şekildedir:

çabun 'talan, yağma'

çap-I 'vurmak, elle vurmak'

çap- II 'akın yapmak, yağmalamak'

çap- III 'atla gitmek, at sürmek, seğirtmek'

çap-IV 'baş kesmek'

çapavul 'yağma, çapul'

çapçı 'sürücü'

çapduk II 'at takımı'

çapgula- 'vuruşmak, döğüşmek'

çapgulaş 'döğüş, muharebe'

çapgulaş- 'dövüşüp vuruşmak'

çapgun I 'koşucu, yörük, korkusuz'

çapgun II 'serseri'

çapguncı 'akıncı', çapış 'at ile hızlı gitme'

çapış- I 'vuruşmak, dövüşmek'

çapış- II 'seğirdişmek'

çapkun II 'koşucu, korkusuz'

çapkun III 'akıncı, baskıncı'

çapkun IV ‘savaş meydanına yardım amacıyla gönderilen bir miktar adam’

çapkura- 'parçalamak'

çapmak '(at) sürme, koşturma, seğirtme'

çaptur- 'koşturmak, akın yaptırmak'

çapuk II 'kılıç ile vurulup küt kalmış şey'

çapuk III 'yörük' (2013: 219, 227-228).

Abuşka Lügatı'nda çap- fiili 'baş kesmek' anlamında gösterilmiştir (Atalay, 1970: 222). Bu anlamla ilişkili olarak çaparsız 'kesersiz (kesersiniz)' ve çapkan 


\section{0}

'kesdüki (kesen)' maddeleri verilmiştir. (Atalay, 1970: 223) Bunlardan başka captl, capıştı, çapturdı, çapıb (Atalay, 1970: 222), çapan (Atalay, 1970: 224) maddelerinin 'seğirtmek (koşmak)' anlamından oluştuğu belirtilmiştir. Ayrıca çapan maddesi için 'baş kesen manasına da gelir' notu düşülmüştür. çapkun maddesinde ise 'ilgar ve akın etmek' anlamında olduğu çapkun sal- fiiliyle örneklendirilmiştir (Atalay, 1970: 221).

Şiban Han Divanı'nda çap- fiili 'vurmak' ve 'kesmek' anlamlarında iki yerde tespit edildi:

min kılı̧nı şer ü̧̈ün çaptım Hudây âgâhdur "Ben kılıcı kötülük için vurdum Tanrı haberdardır" (Karasoy, 1998: 82)

kara zülfüy çapıp Hindu kara kaşıy alıp Multan "Kara zülfün kesip Hindu kara kaşın alıp Multan" (Karasoy, 1998: 207)

Şecere-i Terâkime'de Zuhal Ölmez'in hazırladığı dizine göre; çap- fiili kök olarak yirmi bir yerde 'dörtnala koşmak, koşturmak; yağmalamak, vurmak' anlamlarıyla, çapıl- 1 yerde 'yağmalanmak' anlamıyla, çapış- iki yerde 'vuruşmak, dövüşmek' anlamlarıyla, çaptur- da iki yerde 'koşturmak, yağmalatmak' anlamlarıyla geçmektedir (1996: 359-360). Ancak metinde geçen cümlelere baktığımızda çap- fiilinin on dokuz yerde 'akın etmek, yağmalamak', bir yerde 'kesmek', bir yerde de 'vurmak' anlamıla kullanıldığı görülmektedir. Ölmez'in belirttiği 'dörtnala koşmak, koşturmak' anlamını metinde tespit edemedik:

'vurmak'

çapsa keser (1996: 213/100b-2).

'kesmek'

kllç birlen çapıp (1996: 169/83b-12).

'akın etmek, yağmalamak'

anlarnı köp çapduk (Ölmez, 1996: 109/66a-1).

bolmağanlarnı çaptı (Ölmez, 1996: 130/72 b -9).

Tatarnı çaptı (Ölmez, 1996: 131/73a-2).

Tibetni çapıp (Ölmez, 1996: 142/76b-15).

atkan ve çapkan (Ölmez, 1996: 148/ 78b- 9).

çapip atdılar (Ölmez, 1996: 152/80a-1).

Salur ilini çapıp (Ölmez, 1996: 169/85b-10).

çapkanları yurtlarında olturup (Ölmez, 1996: 169/85b-12). 


\section{)}

çapa başladılar (Ölmez, 1996: 169/85b-18).

barça illerni çapıp (Ölmez, 1996: 182/89b-12).

ilin çapıp (Ölmez, 1996: 183/90a-10).

Suracık ilini çapıp (Ölmez, 1996: 191/92b-16).

köp çaptı (Ölmez, 1996: 196/94b-1).

biribirini çaptı (Ölmez, 1996: 202/96a-14).

biglerni ivlerin çaptı (Ölmez, 1996: 204/97a-19).

Karaşıtnı çapıp (Ölmez, 1996: 204/97b-4).

Enkeşnin ivin çapıp (Ölmez, 1996: 215/101a-6).

ilini çapıp (Ölmez, 1996: 221/103a-6).

Tivecilerni çapdılar (Ölmez, 1996: 226/105a-4).

'yağmalanmak'

çapılğan ilninğ (Ölmez, 1996: 169/85b-13).

'vuruşmak'

çapışurlar irdi (Ölmez, 1996: 168/85a-21).

çapışurlar irdi (Ölmez, 1996: 168/85b-7).

'yağmalatmak'

kişi çapturdılar (Ölmez, 1996: 201/96a-6).

çapturğan aldurğan (Ölmez, 1996: 169/103b-4).

Şeyh Süleyman Efendi-i Buhârî̀nin Lügat-i Çağatay ve Türkî-i Osmanî adlı eserinde çap- fiili ve türevlerine şu şekilde yer verilmiştir:

çap 'yağma', çapagan 'yürük, yolub koşucu, süratle geçici'.

çapavul 'ac dâ [düşman] üzerine sefer itmek, yağma, hücum, târumâr eylemek'.

çap̧̧ı 'hallâc, sürici, akıncı, yagmager'.

çapduk 'at takımı'.

çapgulaş 'dögüş, muhârebe, mücâdele, birbirini kırmak, gavga'.

çapgulamak 'muhârebe itmek, dögüşmek, uruşmak, cenk ve cidâl [kavga] itmek'.

çapgulaşmak 'dögüşüp uruşmak, peyderpey muhârebe itmek, birbirini urmak ve biçmek'.

çapgulaş 'kılıc muhârebesi'.

çapgun 'koşıc1, yürük, serseri; boran, tufan'.

çapguncı 'yagmager, akınc1, sürici'.

çapkuramak 'ziyâde yarelemek, pârçelemek, üst üstine çapmak'. 


\section{J(O)}

çapmak 'atı sürmek, segirtmek, koşdırmak, akın eylemek, atla koşmak; kılıc ile kat ve pâre eylemek'.

çapışmak 'mukâraca ve muzârebe etmek, koşışmak, yügürişmek'.

çapılmak 'urulmak, çarpılmak'.

çapuk I 'kıllıç ile urulub küt kalmış ve çapilmış şeyi'.

çapuk II 'yürük, çabuk, âcil' (Buhârî, 1298/ m. 1882: 144-145).

\subsection{Eski Anadolu Türkçesi ve Osmanll Türkçesinde çap- Fiili:}

Kanar'ın hazırladı̆̆ı Eski Anadolu Türkçesi Sözlüğü’nde çap- fiili ve türevlerine şu şekilde yer verilmiştir:

çabalak 'şaha kalkan'.

çapadüşmek 'yağmaya başlamak, talana başlamak'.

çapar 'haberci, posta tatarı'.

çapdurmak 'yağmalatmak'.

çapgin 'hızlı koşan (at)'.

çapındırmak 'koşturmak, hızlı sürmek'.

çapınmak '1. hızlı hareket etmek, 2. koşmak, 3. saldırmak, hücum etmek'.

çapkın 'hızlı koşan (at)'.

çapkun '1. akın, baskın, 2. hızlı koşan at'.

çapkun etmek 'akın etmek'.

çapma 'koşma, saldırma'.

çapmak '1. at sürmek, at koşturmak, 2. koşmak, 3. vurmak, çarpmak, 4. kesmek, 5. saldırmak, 6. yarmak'.

çaptırmak 'yağmalatmak'.

çapul 'yağma, talan'.

çapul seğirtmek 'akın etmek'.

çapuşmak 'birlikte saldırmak' (2011: 164, 168-169).

Süheyl ü Nevbahar'da çap- fiili '(atı) koşturmak' anlamıyla iki yerde; çapınşekli de 'hızlı yürümek, koşmak' anlamıyla iki yerde geçmektedir:

heman lahza döndi atın depdi ol / be-cid işe varur bigi çapdı ol "O anda döndü atını teperek acele bir işe yetişiyormuş gibi atını koşturdu." (Dilçin, 1991: 360/2451);

revan ata bindi vü depdi atı / güce gördi mişeye çapdı atı "Hemen ata bindi ve atını tepti, atı zorlayarak meşe ormanına koșturdu.” (Dilçin, 1991: 424/3369) 


\section{0}

yüriyen sürinen yügüren uçan / grinen yavinan çapinan kaçan "Yürüyen, sürünen, koşan, uçan,görünen, görünmeyen, hızl yürüyen, kaçan...” (Dilçin, 1991: 197/29)

çeküp üzdi örkini vü ansuzın / çapındı idi ana ol kendüzin "Ayağına bağlanan ipi çekip kopararak aniden ona koştu. O kendini...” (Dilçin, 1991: 455/3834)

Belki de tarih içerisinde çap- fiili ve türevlerinin en çok kullanıldığı metin Kitâb-ı Dedem Korkud'dur. Bu eserde çap- fiili ve türevleri toplamda kırk bir cümlede geçmektedir. Fiilin kök halinin kullanıldığı on yedi cümlenin sekizinde 'atı koşturmak', altısında 'saldırmak, yağmalamak', üçünde 'koşmak' anlamlarında kullanılmıştır.

'atı koşturmak'

... ata binüp... alçakdan yüce yerlere çapup çıkdı "Alçaktan yüksek yerlere atını koşturup çıktı." (Gökyay, 2007: 32)

bidevi atını tutdurdu, batun bindi ... Bogaç Han çapup yetdi "Küheylan atını tutturdu, aceleyle bindi ... Boğaç Han atını koşturup yetişti." (Gökyay, 2007: 35)

çapar-iken ağ boz atuy büdermesün “(Atını) koştururken ak boz atın tökezlemesin." (Gökyay, 2007: 38, 57, 110)

Oguz begleri at çapanda meydan kalmış "Oğuz beyleri at koşturduğunda meydan kalmış." (Gökyay, 2007: 43)

senünle meydanda at çapmadukmu "Seninle meydanda at koşturmadık mı?" (Gökyay, 2007: 86)

atın çekdiler bindi çaptı "Atını çektiler, bindi, koşturdu." (Gökyay, 2007: 166)

'koşmak'

ittifak oglanuy anası oglanuy üstüne çapup çlkageldi “Tesadüfen oğlanın annesi oğlanın üstüne koşup geldi." (Gökyay, 2007: 33)

gerdeklerine çapup düşdüler “Gerdeklerine koşup girdiler.” (Gökyay, 2007: 174)

Kazanuy divanına çapup varuy “Kazan'ın huzuruna koşup gidin.” (Gökyay, 2007: 191)

'saldırmak, yağmalamak'

altun ban evlerin kâfirler çapdılar "Altın çatılı evlerini kâfirler yağmaladılar." (Gökyay, 2007: 40)

bezirgânlar yatur-iken gafille beş yüz kâfir koyuldular, çapdılar, yağmaladılar "Tüccarlar gaflet içinde yatarken beş yüz kâfir geldiler, saldırdılar, yağmaladılar." (Gökyay, 2007: 60)

kanlu kâfir eline akın çapayım "Kanlı kâfir ülkesine akın edeyim, saldırayım”; elin günün çapuy "Evini barkını yağmalayın." (Gökyay, 2007: 122)

kan alaca ordusunu çapun demiş "Kan renkli çadırını yağmalayın, demiş." (Gökyay, 2007: 159) elim günüm çapmadın ... "Evimi barkımı yağmalamadan ..." (Gökyay, 2007: 192) 
Kitâb-ı Dedem Korkud'da çap- fiilinin türevleri olan çapar 'haberci, ulak' ve 'hızla yardıma gelen kişi' anlamında yirmi dört cümlede, çapdur- 'atı koşturmak' anlamında iki cümlede, çapıl- 'saldırılmak, yağmalanmak' anlamında iki cümlede, çapkun 'saldıran, akıncı' anlamında bir cümlede olmak üzere yirmi dokuz kez geçmektedir.

çapar 'haberci, ulak'

Beyregüy atasına anasına muştulukla çapar gitdi "Beyrek'in annesine babasına müjdeyle haberci olarak gitti." (Gökyay, 2007: 86)

at agızlu Aruz Koca evine çapar geldi “At ağızlı Aruz Koca evine haberci geldi.” (Gökyay, 2007: 154)

ag alılu Bayınduruy divanına çapar vardum "Ak alınlı Bayındır'ın huzuruna haberci olarak gittim." (Gökyay, 2007: 157)

ag boz atlu bir çapar geldi “Ak boz atlı bir haberci geldi.” (Gökyay, 2007: 166)

Uşun Kocaya çapar geldi “Uşun Koca'ya haberci geldi.” (Gökyay, 2007: 173)

çapar (yet-) 'hızla yardıma gelen kişi'

Karacuk çoban çapar yetdi “Karacuk çoban hızla yardıma gitti.” (Gökyay, 2007: 51)

Kazan Begüy kardaşı Kara Güne çapar yetdi “Kazan Bey'in kardeşi Kara Güne hızla yardıma gitti." (Gökyay, 2007: 53, 107)

Kıyan Selçük oglu Delü Dundar çapar yetdi, Gaflet Koca oglu Şir Şemseddin çapar yetdi (Gökyay, 2007: 54, 108)

boz aygırlı Beyrek çapar yetdi (Gökyay, 2007: 54, 108)

Kazılık Koca oglu Beg Yegenek çapar yetdi (Gökyay, 2007: 55, 108)

Kazan Begüy dayısı at agızlu Aruz Koca çapar yetdi (Gökyay, 2007: 55, 109)

bıyıgı kanlu Bügdüz Emen çapar yetdi; Eylik Koca oglu Alp Eren çapar yetdi (Gökyay, 2007: 55)

Kazan Begüy kardaşı Kara Güne çapar yetdi (Gökyay, 2007: 107)

Nagâhandan Deli Dumrul çapar yetdi “Aniden Deli Dumrul hızla yardıma gitti.” (Gökyay, 2007: 111)

Salur Kazan kardaşı Kara Güne çapar yetdi (Gökyay, 2007: 162)

çapdur- 'atı koșturmak'

ag boz atlar çapdurur alplar gördüm 'Ak boz atlar koşturan alplar gördüm.' (Gökyay, 2007: 139) kan derledi çapdurayım senüy içün "Kan ter içinde olana kadar at koşturayım senin için." (Gökyay, 2007: 160)

çapıl- 'saldırılmak, yağmalanmak' 


\section{Je)}

elüm günüm çapıldı “Evim barkım yağmalandı." (Gökyay, 2007: 189)

elüm günüm çapılmadın... “Evim barkım yağmalanmadan...” (Gökyay, 2007: 192)

çapkun (yet-) 'saldıran, akıncı'

atıla Karun eline çapkun yetdüm "Atla Karun ülkesine akın ettim, saldırdım." (Gökyay, 2007:

179)

Eski Anadolu Türkçesi dönemine ait satır arası ilk Kur'an tercümesinde de çap- fiili 'hızlı koşmak' anlamında iki cümlede geçmiştir:

bir kişi geldi Musa'ya çapup şehr ahirinden eyitdi “Bir kişi geldi Musa'ya koşup şehrin sonundan söyledi” (Küçük, 2014: 251)

çapǵanda ol atlar ki ayakları taşa dokanıcak od çıkar "Koştuğunda o atlar ki ayakları taşa dokunsa ateş çıkar" (Küçük, 2014: 340)

Mecmuatü'n-Nezâir adlı eserin dizininde çap- fiili için 'atılmak, koşarak gelmek' anlamı verilmiştir (Canpolat, 1995: 283). Fakat metindeki cümleyi incelediğimizde tabirin atın koşturulmasıyla ilgili olduğu görülmektedir:

Seher-geh bir Mugaal oǵlan çapardı ol mana karşu / Muattar atı tozından tüterdi müşk-ile gül-bû "Seher vakti bir Moğol oğlanı (at) koştururdu bana karşı / Itır kokulu atının tozundan misk ve gül kokusu tüterdi” (Canpolat, 1995: 58)

Şerifi'nin Şehname Çevirisi'nde de çap- fiili 'yağma etmek, saldırmak' ve '(at) sürmek, koșturmak' anlamlarıyla çapın- türevi ise 'hızla hareket etmek, atılmak, saldırmak' anlamlarıyla kullanılmıştır:

sürüp irişdi ol iklimi ç̧apdı / nireye ugradl-sa ald l kapd l "[At] sürüp ulaştı o toprakları yağmaladı / nereye uğradıysa (orayı) aldı, kaptı” (Kültüral-Beyreli, 1999: 2092)

bu gün kim oldı Dara'dan yolun pak / çaparsun her yana atunı çalak "Bugün yolun Dara'dan temiz oldu / atını her yana hızlıca koşturursun” (Kültüral-Beyreli, 1999: 2092)

ol aradan turuban ata bindi / o yana bu yana çaldı çapındı "O mesafeden durarak ata bindi / o yana bu yana vurdu, saldırdı" (Kültüral-Beyreli, 1999: 2093)

Tarama Sözlüğü'ndeki örneklere baktığımızda çap- fiili ve türevleri ile ilgili XIV. yüzyıldan başlayarak XVIII. yüzyıla kadar pek çok kullanım görülmektedir. Biz bu sözlükteki bütün örnekleri almayı gerekli görmedik ve her madde başı için birer örnek almakla yetindik. Tarama Sözlü̈̆̈̈’ndeki madde başları ve örnekler ${ }^{22}$ şu şekildedir:

çapadüşmek 'yağma etmeye başlamak'.

${ }^{22}$ Tarama Sözlüğ̈̈’nden alınan örneklerde kaynak eser kısaltmaları sözlükte geçen şekliyle verilmiştir. 


\section{J(e)}

Dil tahta-i meşk olmuş iken tîr-i cefâya

Tatar-ı nigeh garete geldi çapadüştü Ş. Galip XVIII. 248 (TTS, 1995: 821)

çaparız II: Tokat, vuruş. Latmetün bi-lahzatin ya’ni bir kez bakmağa bir çaparız. Tez. Lâ. XV. 682-

2 (TTS, 1995: 822)

çapar ulak (çapar II): Haberi çabuk yetiştirmek için her menzilde atı ve bincisi değişen posta; tatar. Şaha nâgeh irişir çapar ulak Üştü İstanbul'a olmaz ittifak Enverî XV. 89 (TTS, 1995: 823)

Yimek içmek arasında ağ boz atlı bir çapar geldi. Dede E. XIV. 257 (TTS, 1995: 823)

çapgın at (çapkın at): Hızlı koşan at. Ol kadar yürür ki ardından çapgin at yetişmez. Müslim XV. 15, 69 (TTS, 1995: 824)

çapılmak: Yağmalanmak, yağma edilmek. İlim günüm çapıldı. Dede XIV. 149 (TTS, 1995: 824)

çapındırmak: Koşturmak. Âhaniden [Fa.]: çapındırmak Şamil XVI. 336 (TTS, 1995: 824)

çapınmak: Hızlı hareket etmek, atılmak, saldırmak, sür'atle koşmak. Çapındılar kılıçlar ellerindeSanasın yağı vardır illerinde Hurş. XIV. (TTS, 1995: 825)

çapkun etmek: Akın etmek. Nice bin ceng-cûyan ile Azerbaycan üzerine çapkun etmeğe ferman buyrulmuş idi Solak XVII. 286-3 (TTS, 1995: 826)

çapmak 1: Yağma, çapul etmek, saldırmak, atılmak, vurmak, hücum etmek. Çapayım ü yıkayım tahtın anın çerime taladayım rahtın anın Hurş. XIV. 56 (TTS, 1995: 826)

çapmak 2: Koşmak, süratle hareket etmek. Alçaktan yüce yerlere çapup çıktı Dede E. XIV. 26 (TTS, 1995: 826)

çapmak 3: Sürmek, koşturmak.Senin ile meydanda at çapmadı mı? Dede E. XIV. 116 (TTS, 1995: 828)

çapmak 4: Çarpmak, vurup kesmek. Kimin yıkubenin kimin yapasın Nice âsilerin boyun çapasın Tennuri XV. 120 (TTS, 1995: 828)

çaptırmak (çapdurmak) 1: Yağmalatmak, yağma ettirmek. Uruz’un evini çaptırdı.

Dede XIV. 153 (TTS, 1995: 828)

çaptırmak (çapturmak) 2: Koşturmak. Adam çaptırdl şaha muştulayu Ki oğlun geldi üş suçun dileyü Hurş XIV. (TTS, 1995: 828)

çapul: Yağma.Gerdeninde beklesin benler misali karagol Çeşm-i Tatarınla kıl sâmân-1 uşşakı çapul Vasıf XIX. 32 (TTS, 1995: 829)

çapul civermek: Çapulcu göndermek, akın etmek (?). Kâfiristana akınlar ve çapullar civerüp... Ev. XVII. 511 (TTS, 1995: 829)

çapul seğirtmek: Akın etmek. Ta Azak kalesi altına çapul seğirdüp yine Kırım'a avdet ederdi. Ev. XVII. 124 (TTS, 1995: 830)

çapuşmak: Birlikte hücum etmek, koşuşmak. Aşk atına bindiler, çapuştllar. Sır. XVI. 2-8 (TTS, 1995: 830) 
Osmanlı Türkçesinin son dönemlerinde Ahmet Vefik Paşa tarafından hazırlanan Lehçe-i Osmanî̀ de çap- fiili 'çarpmak, vurup koşturmak, atı sürmek, tesrî̀ şeklinde oldukça geniş bir anlam ağıyla tanımlanmıştır (Toparlı, 2000: 88). Sözlükte geçen ve çap- fiilinin türevleri olarak tespit edilebilen kelimeler ise şöyledir:

çapan çapar 'tatar, ulak, çapan galatı, cebbar', çapanak 'kaçırılmış mal'; çapavul 'çapkı askeri, akıncı, ılgarcı; akıncı akıtması, yağmaya saldırma, çapıcı 'sürücü, akıncı', çapkılamak 'atı eştirmek, târâc, yağma, akın etmek', çapkın I 'çapul mall, bk. çapanak', çapkın II 'çapan, yörük, yelip koşucu, atın yürüyüşünden bir ayak açık eşkin tekâvür, çabuk at', çapul 'Türkîde çapılan şey, yağma, menhûbât, gâret, çete', çapulcu 'yağmayı seven kaparozcu, yağma-ger', çapullamak 'hervele, tekütâz, talan', çapullanmak 'iğtinam, kabullenmek, kapıvermek, tu'me almak' (Toparl, 2000: 87-88).

Kamus-ı Türkî'de de çap- fiiline '(at) koşturmak, süratle yürümek; koşmak, süratle öteye beriye salmak; akın ve llgar etmek' anlamları verilmiştir (Yavuzarslan, 2019: 198). Bu fiilin türevleri sayllabilecek örnekler ise Kamus-i Türkî de şu şekilde geçmektedir:

çapan 'tatar, ulak', çapanak ' kaçırılmış mal, kaçak mal', çapar 'tatar, ulak', çapavul 'çapkı askeri, akıncı, llgarcı', çapıcı 'akıncı, sürücü', çapkı 'yağma kastıyla düşman toprağına atla girip her tarafına hücum etme, akın', çapkııı 'akıncı, çapulcu', çapkılamak 'akıncılık etmek, yapma niyetiyle her tarafa at oynatmak', çapkın 'çok yürüyen, çok koşan; açık eşkin giden (at); her tarafa koşup bir yerde dikiş tutmaz, serseri, derbeder; hovarda, sefih, zen-dost, işret ve kumar gibi menhiyata münhemik', çapkınlık 'çapkın adamın hali, sefahat, yolsuzluk, hovardalık', çapul 'düşman toprağını basan akıncıların istedikleri yağma ve gâret, düşman toprağından alınan mal, ganimet', çapul etmek 'nehb ü gâret eylemek', çapulcu 'düşman toprağına atla hücum yani ılgar edip yağma ve gâret eden, akınc1, yağma-ger', çapullamak 'llgar ve akın etmek, düşman toprağında yağma-gerlik eylemek', çapullanmak 'yağma mal kazanmak, ganimet edinmek' (Yavuzarslan, 2019: 198).

\begin{tabular}{|c|c|c|}
\hline \multicolumn{3}{|c|}{ Çap- Fiili Ve Türevlerinin Tarihî Türk Lehçelerinde Kullanımları } \\
\hline Tarihî Lehçe & Fiil Olarak Kullanılan Şekiller & İsim Olarak Kullanılan Şekiller \\
\hline $\begin{array}{l}\text { Uygur Türkçesi } \\
\text { Dönemi }\end{array}$ & çap- 'vurmak' & çapça 'dirgen, tırmık' \\
\hline $\begin{array}{c}\text { Karahanlı Türkçesi } \\
\text { Dönemi }\end{array}$ & 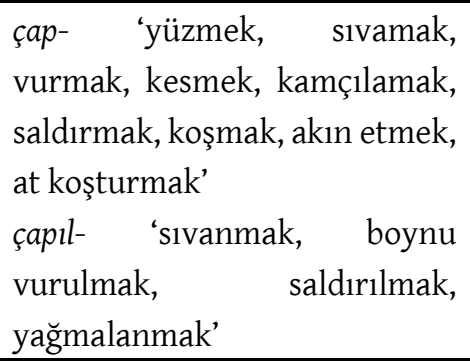 & $\begin{array}{l}\text { çapıtgan 'çok saldıran' } \\
\text { çapıtgan er 'cellat, boyun vuran' } \\
\text { çawı 'kamçı, kamçı ucu' }\end{array}$ \\
\hline
\end{tabular}




\begin{tabular}{|c|c|c|}
\hline & $\begin{array}{l}\text { çapın- 'kamçılamak, yüzmek, } \\
\text { hızlı yürümek, koşmak' } \\
\text { çapıt- 'saldırmak, boyun } \\
\text { vurdurmak' } \\
\text { çapsa- 'yüzmek istemek' } \\
\text { çaptur- 'suda yüzdürmek, } \\
\text { çamurla sivatmak, boynunu } \\
\text { vurdurmak, atı koşturmak' }\end{array}$ & \\
\hline $\begin{array}{c}\text { Harezm Türkçesi } \\
\text { Dönemi }\end{array}$ & $\begin{array}{l}\text { çap- 'kesmek, parçalamak; (el) } \\
\text { vurmak, yüzmek; koşmak, (at) } \\
\text { koşmak' } \\
\text { çapıt- '(kalpiçin) çarptırmak' } \\
\text { çaptur- 'koşturmak, } \\
\text { koşuşturmak' } \\
\text { çapturt- } \\
\text { kestirmek' } \\
\text { çapul- 'perçalatmak, } \\
\text { dağılmak, atılmak' }\end{array}$ & $\begin{array}{l}\text { çabük süvar/çawüksüvar 'ata iyi } \\
\text { binen, binici' }\end{array}$ \\
\hline $\begin{array}{c}\text { Kıpçak Türkçesi } \\
\text { Dönemi }\end{array}$ & $\begin{array}{l}\text { çap- 'koşmak; atılmak, hızlı } \\
\text { hareket etmek; sürmek, at } \\
\text { koşturmak; vurmak, çarpmak; } \\
\text { kılıç vurmak; bir defada hem } \\
\text { vurmak hem kesmek; yüzmek, } \\
\text { suda çırpınmak; derisi } \\
\text { soyulmak, yağır olmak' } \\
\text { çapdur- 'çaptırmak, koşturmak' } \\
\text { çapın- 'birden hücum etmek; } \\
\text { elin ayası ile vurmak' } \\
\text { çapla- 'boyna bir şey takmak' } \\
\text { çaplat- 'şaplak indirme, tokat } \\
\text { vurma' } \\
\text { çapul- 'atılmak, vurulmak' } \\
\text { şap- 'çarpmak, vurmak, bir } \\
\text { aygitla vurmak, sürmek' } \\
\text { şapla- 'taş yontmak' }\end{array}$ & $\begin{array}{l}\text { şapış 'sürme' } \\
\text { şaplama 'şaplak, tokat' }\end{array}$ \\
\hline $\begin{array}{c}\text { Çağatay Türkçesi } \\
\text { Dönemi }\end{array}$ & $\begin{array}{l}\text { çap- 'akın yapmak, } \\
\text { yağmalamak; atla gitmek, at } \\
\text { sürmek, seğirtmek; baş } \\
\text { kesmek' } \\
\text { çapgula- 'vuruşmak, döğg̈şşmek' } \\
\text { çapgulaş- 'dövüşüp vuruşmak' } \\
\text { çapış- 'vuruşmak, dövüşmek; } \\
\text { seğirdişmek' } \\
\text { çapkun sal- 'ilgar ve akın etmek' }\end{array}$ & $\begin{array}{l}\text { çabun 'talan, yağma' } \\
\text { çap 'yağma' } \\
\text { çapagan 'koşucu, süratle geçici' } \\
\text { çapan 'koşan; baş kesen' } \\
\text { çapavul 'yağma, çapul' } \\
\text { çapçı 'sürücü, akıncı' } \\
\text { çapduk 'at takımı' } \\
\text { çapgulaş 'dövüş, muharebe' }\end{array}$ \\
\hline
\end{tabular}




\begin{tabular}{|c|c|c|}
\hline & $\begin{array}{l}\text { çapkura- 'parçalamak' } \\
\text { çaptur- 'koşturmak, } \\
\text { yaptırmak' }\end{array}$ & $\begin{array}{l}\text { çapgun 'koşucu, korkusuz; } \\
\text { serseri' } \\
\text { çapguncı 'akıncı' } \\
\text { çapış 'at ile hızlı gitme' } \\
\text { çapkan 'kesdüki (kesen) } \\
\text { çapkun 'koşucu, korkusuz; } \\
\text { akıncı, baskıncı; savaş } \\
\text { meydanına yardım amacıyla } \\
\text { gönderilen bir miktar adam' } \\
\text { çapmak '(at) sürme, koşturma, } \\
\text { seğirtme' } \\
\text { çapuk 'kılıç ile vurulup küt } \\
\text { kalmış şey; çabuk, acil' }\end{array}$ \\
\hline $\begin{array}{l}\text { Eski Anadolu ve } \\
\text { Osmanlı Türkçesi } \\
\text { Dönemi }\end{array}$ & $\begin{array}{l}\text { çap- 'at sürmek, at koşturmak; } \\
\text { koşmak; vurmak, çarpmak; } \\
\text { kesmek; saldırmak; yarmak' } \\
\text { çapadüş- 'yağmaya başlamak, } \\
\text { talana başlamak' } \\
\text { çapar yet- 'hızla yerdıma } \\
\text { gitmek' } \\
\text { çapdur- 'yağmalatmak' } \\
\text { çapındır- 'koşturmak, hızlı } \\
\text { sürmek' } \\
\text { çapın- 'hızlı hareket etmek; } \\
\text { koşmak; saldırmak, hücum } \\
\text { etmek' } \\
\text { çapkıla- 'yağma, akın etmek' } \\
\text { çapkun et- 'akın etmek' } \\
\text { çapkun yet- 'akın etmek, } \\
\text { saldırmak' } \\
\text { çaptır- 'yağmalatmak' } \\
\text { çapul civer- } \\
\text { göndermek, akın etmek' } \\
\text { çapul et- 'yağma etmek' } \\
\text { çapulla- 'ılgar ve akın etmek' } \\
\text { çapullan- 'yağma } \\
\text { kazanmak, ganimet edinmek' } \\
\text { çapul seğirt- 'akın etmek' } \\
\text { çapuş- 'birlikte saldırmak' }\end{array}$ & $\begin{array}{l}\text { çabalak 'şaha kalkan' } \\
\text { çapan/çapar 'haberci, posta } \\
\text { tatarı' } \\
\text { çapanak 'kaçırılmış mal' } \\
\text { çaparız 'tokat, vuruş' } \\
\text { çapar ulak 'haberci, posta' } \\
\text { çapavul 'çapkı askeri, akıncı, } \\
\text { 1lgarcı; akıncı akıtması, } \\
\text { yağmaya saldırma' } \\
\text { çapgın 'hızlı koşan (at)' } \\
\text { çapıcı 'akıncı, sürücü' } \\
\text { çapkı 'yağma kastıyla düşman } \\
\text { toprağına atla girip her } \\
\text { tarafına hücum etme, akın' } \\
\text { çapkıcı 'akıncı, çapulcu' } \\
\text { çapkın 'çapul malı; hızlı koşan } \\
\text { (at); serseri, derbeder, hovarda' } \\
\text { çapkınlık 'çapkın adamın hali, } \\
\text { yolsuzluk, hovardalık' } \\
\text { çapkun 'akın, baskın' } \\
\text { çapma 'koşma, saldırma' } \\
\text { çapul 'çapılan şey, yağma, talan, } \\
\text { ganimet' } \\
\text { çapulcu 'düşman toprağına atla } \\
\text { hücum yani ılgar eden akıncı' }\end{array}$ \\
\hline
\end{tabular}

Tablo I, Tarihi Türk Lehçeleri Tablosu 


\section{J(৫)}

\section{Türkiye Türkçesi ve Anadolu Ağızlarında çap- Fiili:}

Çalışmamızın konusu olan çap- fiilinin farklı sahalarda ve farklı dönemlerde tarihi metinlerimizdeki kullanımları yukarıdaki gibidir. Şimdi de öncelikle günümüzde Türkiye Türkçesi ve ağızlarındaki kullanım şekillerine daha sonra da lehçelerimizdeki kullanım şekillerine değineceğiz.

Türkiye Türkçesinin temel kaynağı olan Türkçe Sözlük'te çap- fiiliyle ilgili çok geniş bilgilere rastlanmamaktadır. Sadece çapmak 'koşturmak; akın etmek, koşmak' ve çapar 'postacı, ulak' maddelerinin 'eskimiş' notuyla verilmiş yani günümüzde kullanılmadığına değinilmiştir (TS, 2005: 393-394).

Türkiye Türkçesinin ağızları söz konusu olduğunda ise çap- fiilinin çok yaygın bir kullanıma sahip olduğu görülmektedir: çapmak (I) 'koşmak, ivmek', çapmak (II) 'köpek havlamak', çapmak (III) 'kesmek' (DS, 1968: 1077) gibi kullanımların yanında çapa çapa 'koşa koşa' (DS, 1968: 1072), çapcak-çapcıkçapıçak-çapik-çapık 'çabucak', çapdırmak 'koşturmak' (DS, 1968: 1074), çapıl 'yağma, ganimet', çapını açmak 'hızlandırmak' (DS, 1968: 1075), çapkı (II) 'bir şeyi yağmalamak için yapılan akın', çapkıcı 'akıncı', çapkılamak 'akın etmek', çapkın (II) ‘her gördüğü eşyayı alan' (DS, 1968: 1076) gibi kelimelerin fiilin tarihi seyrindeki anlamlarla örtüştüğü görülmektedir.

\section{4. Çağdaş Türk Lehçelerinde çap- Fiili:}

Türkiye Türkçesi ağızlarında yaygın bir kullanıma sahip olan çap- fiilinin Türkiye Türkçesi yazı dilinde asli fiil olarak kullanılmadığını belirtmiştik. Ancak çağdaş lehçelerimiz söz konusu olduğunda fiilin bazı ses ve şekil değişiklikleriyle yaygın bir şekilde kullanıldığı görülmektedir. Fiilin lehçelerimizdeki kullanım şekilleri şu şekildedir:

\begin{tabular}{||c||l||}
\hline \hline Lehçe & \multicolumn{1}{|c||}{ 'Çap-' Fiili ve Türevlerinin Çağdaş Türk Lehçelerinde Kullanımları } \\
\hline \hline \multirow{3}{*}{ Türkiye Türkçesi } & çapar (eskimiş) 'postacı, ulak' \\
& çapkın 'geçici aşklar ve ilişkiler peşinde koşan kimse, hovarda' \\
& çapmak (eskimiş) '1. koşturmak, 2. akın etmek, koşmak' \\
& çapul 'yağma, talan, plaçka' \\
& çapulcu 'başkasının malını alan, yağma, talan eden kimse, talanc1, yağmacı, \\
& plaçkacı' \\
& çapulculuk 'çapulcunun yaptı̆̆ iş veya davranış' \\
& çapullama 'çapullamak işi’ \\
\hline
\end{tabular}




\begin{tabular}{|c|c|}
\hline & çapullamak 'bir yeri soymak, yağmalamak' (TS, 2005: 393-395) \\
\hline $\begin{array}{c}\text { Azerbaycan } \\
\text { Türkçesi }\end{array}$ & $\begin{array}{l}\text { çapacag 'satır' çapağan 'süratli koşan at' } \\
\text { çapar '1. eskiden atla bir yere mektup, emir, haber götürüp getiren adam, } \\
\text { ulak, posta, tatar, 2. atlı muhafız' } \\
\text { çaparag 'koşarak, hızlı bir şekilde, koşa koşa' } \\
\text { çaparaglamag '1. süratle gitmek veya gelmek, koşmak, 2. atı hızlı sürmek' } \\
\text { çaparhana 'eskiden ulakların (postaların) bir haberi vs.'yi yerine hızla } \\
\text { ulaştırabilmek için yol üzerinde yapılan konaklama yerleri, atların veya } \\
\text { postaların değiştirildikleri yerler' } \\
\text { çapgın 'soygun maksadıyla yapılan silahlı baskın, yol kesme' } \\
\text { çapgınçı 'soyguncu, eşkıya, şaki' } \\
\text { çapıg '1. vücudun herhangi bir yerinde iyileşmiş yara yeri, iz, 2. bir şeyin } \\
\text { üzerinde olan uzunlamasına oyuk, çizik, 3. üzerinde iz olan' } \\
\text { çapılıb-talanmag 'yağma edilmek, soyulmak' } \\
\text { çapılmag 'satır, balta vs. ile parçalanmak, doğranmak, yaralanmak' } \\
\text { çapıl(r)tmag 'hızlı sürmek, koşturmak, dört nala sürmek (at)' } \\
\text { çapış̧ 'dört nala sürme, koşturma işi (at)' } \\
\text { çapışmag 'at yarıstıtırmak, atla yarışmak' } \\
\text { çapmak '1. satır, balta, keser vs. ile parçalamak, yarmak, 2. hıllı sürmek, } \\
\text { koşturmak; kaçıp gitmek, 3. zorla veya başka bir yolla elindekileri almak, } \\
\text { soyup soğana çevirmek, 4. keskin bir şeyle yaralamak' } \\
\text { çapovul 'Soygun, talan' (Altayll, 1994: 191-192) }\end{array}$ \\
\hline Türkmen Türkçesi & $\begin{array}{l}\text { çap-I 'koşmak' } \\
\text { çap-II '1. kesmek, parçalamak, 2. yağmalamak, talan etmek, 3. mec. } \\
\text { öldürmek, kesmek' } \\
\text { çapagan 'iyi koşan, çevik, yürük (at, eşek) } \\
\text { çapar 'atlı haberci, ulak' } \\
\text { çaparman 'bk. çapagan' } \\
\text { çapavul '1. kurye, 2. yağma, çapulculuk' } \\
\text { çapavulçllık 'yağmacıllk' } \\
\text { çapavulla- 'yağma etmek' } \\
\text { çapavullı 'bk. çapavulçllı' } \\
\text { çapdır- 'bk. çap-I, çap-II' } \\
\text { çapgı 'satır' } \\
\text { çapgıla- 'satırla kesmek, doğramak' } \\
\text { çapgın '1. yağmacılık, 2. mec. şiddetli, keskin (soğuk, ayaz, rüzgar) } \\
\text { çapgınlaşmak ‘soğumak, ayaz olmak' } \\
\text { çapgır I 'iyi koşan, yürük (at)' } \\
\text { çapgır II 'keskin' } \\
\text { çapık '1. kesik, 2. kesilen ya da yarılan yerin izi' } \\
\text { çapıksuvar 'at yarışçısı, cokey' } \\
\text { çapıl- 'bk. çap-I, çap-II' } \\
\text { çapım-çapım 'kesik kesik, parça parça' } \\
\text { çapış- 'bk. çap-I, çap-II' }\end{array}$ \\
\hline
\end{tabular}




\section{$\mathrm{J}($ (৫)}

\begin{tabular}{|c|c|}
\hline & $\begin{array}{l}\text { çapışılk I 'at yarışı' } \\
\text { çapışık II 'savaş, kırım’ } \\
\text { çapuv '1. koşu, 2. bk. çapışık I' (Tekin, 1995: 1110-111) }\end{array}$ \\
\hline Gagavuz Türkçesi & $\begin{array}{l}\text { çapanak '1. ganimet, 2. ürün, gelir, kâr' } \\
\text { çapkın 'çapkın' çapkınnamaa 'süratlenmek' } \\
\text { çapkınnık 'yaramazlık' (Baskakov, 1991: 52) }\end{array}$ \\
\hline $\begin{array}{l}\text { Yeni Uygur } \\
\text { Türkçesi }\end{array}$ & 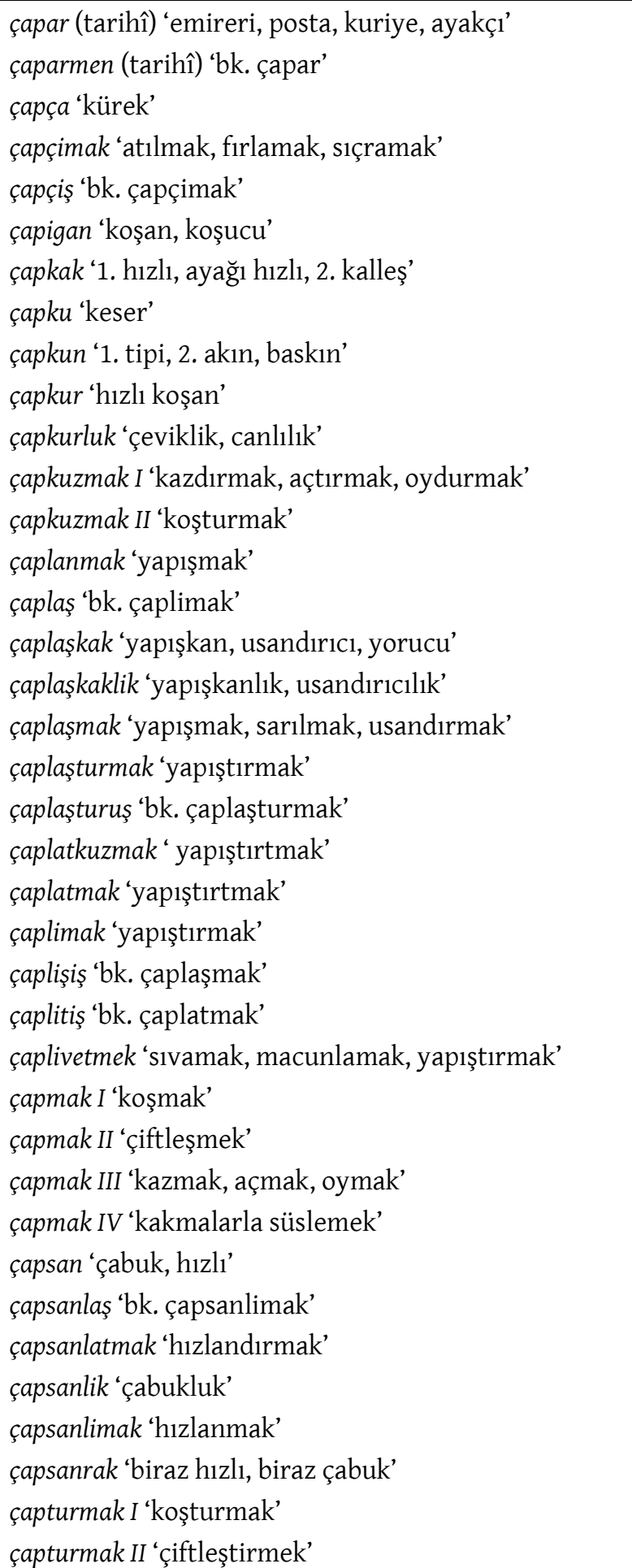 \\
\hline
\end{tabular}




\begin{tabular}{|c|c|}
\hline & $\begin{array}{l}\text { çapturmak III 'kazdırmak, oydurmak, açtırmak' } \\
\text { çapturuş I ‘bk. çapturmak I' } \\
\text { çapturuş II 'bk. çapturmak II' } \\
\text { çapturuş III ‘bk. çapturmak III' (Necip, 1995: 70-71) }\end{array}$ \\
\hline Özbek Türkçesi & $\begin{array}{l}\text { chapimoq 'bulaştırmak, sürmek, yağlamak' } \\
\text { chaplamoq 'sürmek, yağlamak; sıvamak, düzensiz sürmek, düzensiz } \\
\text { yağlamak' } \\
\text { chaplashmoq 'bulaşmak; sıvamak' } \\
\text { chopar (tarihi) 'kurye, ulak, haberci' } \\
\text { chopag 'on 'çok koşan, hızlı koşan' } \\
\text { chopmoq I 'koşmak, koşturmak' } \\
\text { chopmoq II 'kesmek, yontmak, kazmak' } \\
\text { chopki 'satır, bıçak' } \\
\text { chopkillamoq 'hızla koşmak, koşturmak' } \\
\text { chopkir 'hızlı koşan' } \\
\text { choptirmoq 'kestirmek; koşturmak; işemek' (Üşenmez, 2016: 544, 549) }\end{array}$ \\
\hline Hakas Türkçesi & $\begin{array}{l}\text { çapçañ '1. hızlı, atik, çevik, hareketli, 2. becerikli, eli uzun, hamarat, işgüzar' } \\
\text { çappas '1. vurma hareketi, 2. (balçık kaplar yapımında, kabın kenarlarını } \\
\text { vurarak sıkıştırmak için kullanılan) küçük kürek' } \\
\text { çapras 'bk. çappas' } \\
\text { sabıl ı '1. dövülmek, dayak yemek, 2. (yün) dövülmek, 3. (kötü koku) } \\
\text { yayılmak, dağılmak' } \\
\text { sabın I '(ot) biçme, biçim' } \\
\text { sabın II 'nişan tahtası, hedef } \\
\text { sabın '1. dövünmek, kendini dövmek, 2. hamamda terlemek, 3. göbek } \\
\text { taşında yatmak' } \\
\text { sabıncah 'hamamda yıkanma sırasında masaj için kullanılan, ağaç } \\
\text { dallarından yapılmış demet' } \\
\text { sabındı '1. biçilmiş ot, 2. avluyu kardan koruyan, söğüt dallarından örülmüş } \\
\text { çit' } \\
\text { sabırat- '(suda) çırpınmak, yüzmek için gayret göstermek' } \\
\text { sabıs '(yumrukla) vuruş, darbe' } \\
\text { sabıs- 'dövüşmek, vuruşmak, (birlikte) kavga etmek, yumruklaşmak' } \\
\text { sap- '1. vurmak, dövmek, 2. çarpmak, 3. (ot) biçmek, 4. (yün) dövmek, 5. } \\
\text { rüzgar esmek, 6. (el) sallamak, çırpmak' } \\
\text { saphı 'tırpan, orak' saphılan-'(suda) çırpınmak, çabalamak' } \\
\text { saphın 'süvari müfrezesi, atlı müfzere' } \\
\text { sappa 'balta' sappacah '(küçük) balta, nacak' (Naskali, 2007: 79, 414-415, } \\
424) \text {. }\end{array}$ \\
\hline Altay Türkçesi & $\begin{array}{l}\text { çapagan 'dörtnala gezmeyi seven' } \\
\text { çabiju '1. kesme, 2. yarışma' } \\
\text { çabın- '1. hızlı gitmek, 2. buharlaşmak, 3. yanlarına vurmak' } \\
\text { çabış ‘1. koşu; kaçma, 2. kavga, çarpışma' } \\
\text { çabış- '1. birlikte kesmek, 2. kavga etmek, 3. yarışmak' }\end{array}$ \\
\hline
\end{tabular}




\begin{tabular}{|c|c|}
\hline & $\begin{array}{l}\text { çabıştır- '1. kavga ettirmek, 2. yarıştırmak' } \\
\text { çabu '1. hızlı gidiş, 2. koşu' } \\
\text { çap- '1. hızla, dörtnala koşmak, 2. kesmek' } \\
\text { çapçl- 'tırnakla, toynakla vurmak' } \\
\text { çapkı '1. orak, 2. kapan' } \\
\text { çapkıs ‘balta, keser' (Naskali, 1999: 68, 70). }\end{array}$ \\
\hline Kırgız Türkçesi & $\begin{array}{l}\text { çabaagan '(bir iş hakkında) haber salmak için komşu avullara (köylere) } \\
\text { gönderilen sâi [ulak], } \\
\text { çabaagançı 'çabaagan' } \\
\text { çabar '1. sâi (tatar); salıkçı (haberci), 2. kavas; kurye' } \\
\text { çabarman '1. seyis, atlı, 2. kurye' } \\
\text { çabendes 'at üzerinde oğlakla yapılan yarışta oğlak çekmekte mahir olan; } \\
\text { cesur, atılgan atlı' } \\
\text { çabıl- '1. dibinden kesilmek, 2. çapula ve yağmaya çarpmak, 3. dört nala } \\
\text { koşmak (binek hayvanı hakkında) } \\
\text { çabım '[atlar için] yarışların mesafesi' } \\
\text { çabıs I 'yarış, koşu' } \\
\text { çabıs II '1. hep beraber kesmek; birbirini kesmek, 2. koşmak suretiyle } \\
\text { yarışmak; alabildiğine koşmak' } \\
\text { çabısuu 'çabış- II' } \\
\text { çabıt 'şikâr [av] araştırarak dolaşmak; baskın, akın' } \\
\text { çabıtta- 'av arayıp dolaşmak' } \\
\text { çabuul '1. hızlı yürüyüş (at üzerinde); koşu, 2. akın, çapul, taarruz, hücum' } \\
\text { çabuulda- '1. muayyen bir yönet gözetmeksizin koşturmak (atı), 2. dört nala, } \\
\text { dolu dizgin koşturmak' } \\
\text { çabuuldat- 'çabuulda-' } \\
\text { çap- IV '1. hızlı koşmak, 2. kesmek, 3. atılmak' } \\
\text { çapçan 'çapçang' } \\
\text { çapçang 'çabuk, çeviklikle, hızlı, hareketlerinde süratli ve çevik' } \\
\text { çapçangdık 'sürat, çeviklik, eline ayağına çabuklu; ustalık' } \\
\text { çapç- 'ön ayağıyla, tırnağıyla yere vurmak (at, yabani hayvan hakkında)' } \\
\text { çapçla- 'çapç1-' } \\
\text { çapkıç 'kesen aygıt (alet)' } \\
\text { çapkıla- 'çap- IV’ten vurmak' } \\
\text { çapkınçllk '1. katliam, toptan öldürme, imha, 2. akınlar zamanında huzur ve } \\
\text { rahatın bulunmadığ1 zaman.' } \\
\text { çapma '1. yürük at, 2. oyma, kazma' } \\
\text { çapmaluu 'kakmalı' } \\
\text { çapta- '1. tıkamak, sımsıkı kapatmak, 2. zamkla yapıştırmak; bir nesneyi } \\
\text { diğer bir şeye yapıştırmak, bir şeyi başka bir nesnenin üzerine yapıştırmak' } \\
\text { çaptal- 'çapta-' } \\
\text { çaptat- 'çapta-' } \\
\text { çaptır- 'çap- IV'ten kakmak, yarıştırmak' } \\
\text { çaptoo 'çapta-' (Yudahin, 1998: 240-242, 251-252). }\end{array}$ \\
\hline
\end{tabular}




\begin{tabular}{|c|c|}
\hline Kumuk Türkçesi & $\begin{array}{l}\text { çabılmaq I 'çapmaq I'den edilgen' } \\
\text { çabılmaq II 'çapmaq II'den edilgen; temizlenmek, yontulmak' } \\
\text { çabılmaq III 'çapmaq III'ten edilgen; badanalamak' } \\
\text { çabışıw 'çabışmaq'tan iş ismi' } \\
\text { çabışmaq ' çapmaq II'den işteş' } \\
\text { çabıw I '1. koşu, 2. at koşusu, at yarışı' } \\
\text { çabıı II 'kesme, doğrama; yonma, yontma' } \\
\text { çabıw III 'badanalama' } \\
\text { çabıwul (eskimiş) '1. baskın, akın (atlarla), 2. koşuşma, telaş’ } \\
\text { çapğı ‘satır' } \\
\text { çapğın 'akın, baskın, saldırı, taarruz' } \\
\text { çapğınçı 'soyguncu' } \\
\text { çapğılılı 'çapğın'dan soyut isim' } \\
\text { çapmaq I 'koşmak' } \\
\text { çapmaq II '1. kesmek, kıymak, doğramak, 2. yonmak, yontmak' } \\
\text { çapmaq III ‘badana etmek, badana vurmak, badanalamak' (Pekacar, 2011: 95, } \\
\text { 97-98). }\end{array}$ \\
\hline $\begin{array}{c}\text { Kazan Tatar } \\
\text { Türkçesi }\end{array}$ & $\begin{array}{l}\text { çabagaç 'harman makinesi, patoz' } \\
\text { çabar 'acil bir haberle bir yere göderilen kişi, ulak' } \\
\text { çabın- 'saunada yıkanırken yapraklı dal demetiyle dövünmek' } \\
\text { çabındı 'ot biçme' } \\
\text { çabış '1. at yarışı, 2. hızlı koşma şekli' } \\
\text { çabış- '1. birlikte koşuşmak, 2. koşuşturrmak, telaşa kapılmak, 3. at } \\
\text { koşusunda yarışmak.' } \\
\text { çabış̧ı ' '1. koşucu, yarış̧ı, 2. koşu atı' } \\
\text { çabışıı 'koşu atı' } \\
\text { çap- '1. pek hızlı, pek çabuk gitmek, (atlar için) hızla koşmak, 2. koşarak } \\
\text { yarışmak, 3. vurmak, 4. bir işin peşini bırakmamak, 5. bir kadını takip } \\
\text { etmek.' } \\
\text { çapalak I 'şaplak, tokat' } \\
\text { çapalak II 'sineklik, sinek öldürmek için yapılmış, saplı alet' } \\
\text { çapkı 'çapa' çapkıç 'orak makinesi' } \\
\text { çapkın '1. acil bir işle gönderilen ulak, 2. hızlı koşan küheylan' } \\
\text { çaptır- '1. atı yarıştırmak, 2. kovalayarak koşturmak, 3. pek çabuk hareket } \\
\text { etmek, çabucak gitmek' (Öner, 2009: 59, 62). }\end{array}$ \\
\hline $\begin{array}{c}\text { Kırım Tatar } \\
\text { Türkçesi }\end{array}$ & $\begin{array}{l}\text { çabalamaq 'dört dönmek, kendini oradan oraya atmak, yüpürmek, } \\
\text { koşuşmak' } \\
\text { çapa-çapa 'koşa koşa, koşarak' } \\
\text { çapıs 'koşu' } \\
\text { çapışmaq 'koşuşmak' } \\
\text { çapqalamaq 'dört dönmek, kendini oradan oraya atmak, yüpürmek' } \\
\text { çapqalanmaq 'koşuşmak, yüpürmek' } \\
\text { çapqin 'çapkın' } \\
\text { çapqinlıq 'çapkınlık' }\end{array}$ \\
\hline
\end{tabular}




\begin{tabular}{|c|c|}
\hline & çapmaq 'koşmak' (Muzafarov, 2018: 77, 79). \\
\hline $\begin{array}{c}\text { Karaçay-Balkar } \\
\text { Türkçesi }\end{array}$ & $\begin{array}{l}\text { çab- I 'saldırmak' } \\
\text { çab- II 'koşmak' } \\
\text { çaba-corta 'koşuşturarak' } \\
\text { çabdır- 'koşturmak' } \\
\text { çabhın 'eşkin ile dörtnal arası at koşusu' } \\
\text { çabış- 'koşuşmak' } \\
\text { çabuv I 'saldırı' } \\
\text { çabuv II 'koşu' } \\
\text { çabuvçu 'koşucu' } \\
\text { çabuvuk 'süratli, hızlı, seri' } \\
\text { çabuvul 'saldırı, hücum' (Tavkul, 2000: 164-165). }\end{array}$ \\
\hline Karayim Türkçesi & $\begin{array}{l}\text { çabay-turgan 'koşucu' } \\
\text { çabuvul 'saldırı, baskın, soygun' } \\
\text { çabuvçu 'bk. çabuvçı' } \\
\text { çabuvçı '1. taş kesen, 2. ağaç kesen' } \\
\text { çabul 'saldırı, baskın' } \\
\text { çabul- '1. şöhret olmak, tanınmak, 2. dalgalanmak, hareketlenmek (su } \\
\text { hakkında), 3. kesilmek, 4. parçalanmak' } \\
\text { çabul 'saldırı' } \\
\text { çap- I 'koşmak, yarışmak' } \\
\text { çap- II '1. dövmek, vurmak, 2. kesmek, dilimlemek, oymak, 3. kesmek, } \\
\text { doğramak' } \\
\text { çapkın ' çapkın, oynak' } \\
\text { çapkınlık 'çapkınlık, oynaklık' } \\
\text { çapma 'kesme, dilimleme' } \\
\text { çaptır- 'koşturmak' } \\
\text { çapul- 'kesilmek' (Baskakov, 1974: 619-620, 624). }\end{array}$ \\
\hline Kazak Türkçesi & $\begin{array}{l}\text { şabandoz '1. at binicisi, jokey, 2. belli bir sanatın, işin ustassı; duayen' } \\
\text { şabarman (arkaik) 'ulak, haberci' } \\
\text { şabuvıl '1. saldırı, hücum, 2. at çobanlarının gün boyu atlarla oraya buraya } \\
\text { koşturması, 3. hücum, atak' } \\
\text { şabuvılda- '1. devamlı hücum etmek, saldırmak, ileri atılmak, 2. (insanlar) } \\
\text { koşuşmak, hareketlenmek, 3. atağa geçmek, hücum etmek. } \\
\text { şabuvıldavşı 'hücum eden, saldıran, baskın yapan kimse' } \\
\text { şabuvılş̧ı '1. düşmana saldıranlar, hücum edenler, akıncılar, 2. (spor) akıncı, } \\
\text { forvet, ileri uç oyuncusu, hücum oyuncusu' } \\
\text { şabıs '1. (at için) koşma, 2. at yarışı, 3. hız, sürat' } \\
\text { şabıs- 'savaşmak, çarpışmak' } \\
\text { şabısker 'at binicisi, jokey' } \\
\text { şabıstı 'yürük, hızlı koşan (at)' } \\
\text { şap- II 'dört nala, dolu dizgin gitmek' } \\
\text { şap- III 'keskin bir aletle kesmek, biçmek' } \\
\text { şap- IV ‘bir şeye yapışmak, tununup kalmak' }\end{array}$ \\
\hline
\end{tabular}




\begin{tabular}{|c|c|}
\hline & 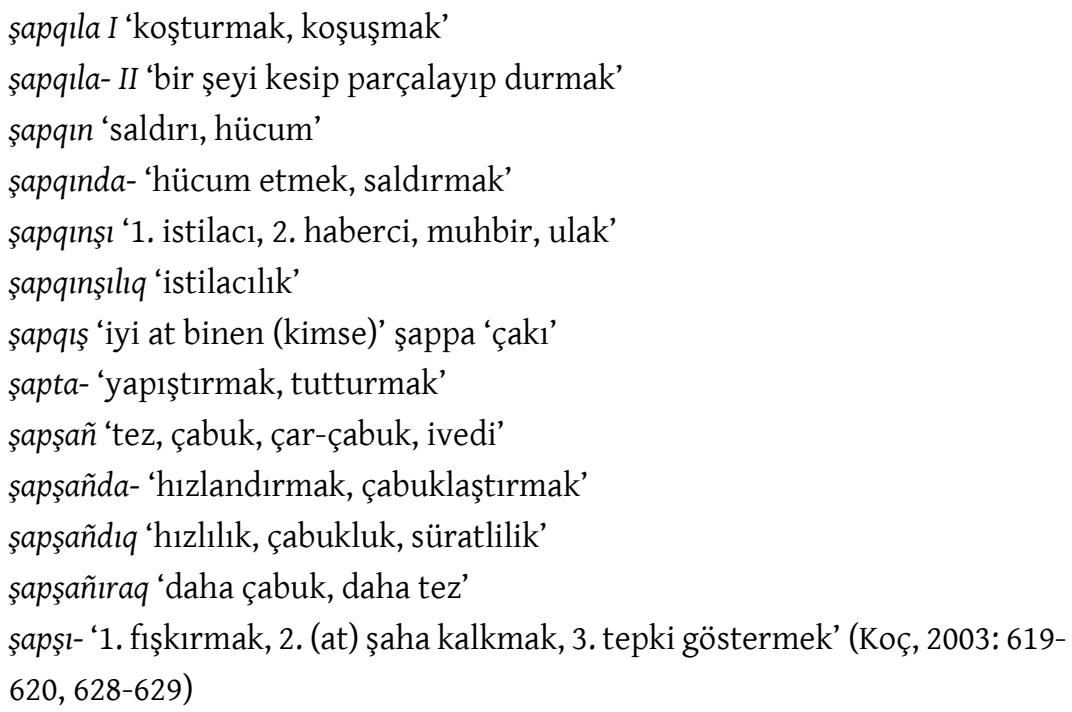 \\
\hline Başkurt Türkçesi & $\begin{array}{l}\text { sabar '1. hükümdar muhafızı, çar muhafızı, 2. acil bir haberle bir yere } \\
\text { gönderilen kişi, ulak' } \\
\text { sabarman 'acil bir haberle bir yere gönderilen kişi, ulak' } \\
\text { sabıl- 'biçilmek, kesilmek, vurulmak; ekin derilmek' } \\
\text { sabım 'biçilmiş ekin, derilmiş ekin' } \\
\text { sabın 'ekin biçilen yer, ekin tarlası' } \\
\text { sabın- 'saunada yapraklı dal demetiyle dövünmek' } \\
\text { sabındı 'inşaat ve yol yapımında kullanılan kesme taş' } \\
\text { sabındır- 'saunada yapraklı dal demetiyle dövdürüp yıkamak' } \\
\text { sabınlık 'bk. sabın'. } \\
\text { sabış- ' '1. karşllılı yüze, yanağa vurmak, 2. koşuda yarışmak' } \\
\text { sabış- II '1. birlikte biçmek, birlikte kesmek, birlikte dermek' } \\
\text { sabıs 'at koşusu, at yarışı' } \\
\text { sabışkl 'iyi koşan, hızlı koşan (at için)' } \\
\text { sabıştır- 'koşturmak, koşuda yarıştırmak' } \\
\text { sabıvll 'beklenmedik anda yapılan baskın, ani saldırı' } \\
\text { sabıvılla- 'sağa sola koşturup huzursuzlanmak' } \\
\text { sabıvla- '1. hızlı hızlı hareket etmek, 2. aceleyle sağa sola koşmak' } \\
\text { sabıvsı 'ekin biçen kimse, ekin deren kimse' } \\
\text { sap-I 'sıçrayarak ve hızlıca koşmak (hayvanlar için); pek hızlı ve çabucak } \\
\text { gitmek' } \\
\text { sap- II ' '1. gerinerek hızlıca vurmak (yanağa, yüze), 2. sauna içerisinde } \\
\text { yaprak demeti ile vurmak, 3. kesmek, biçmek, kırmak'. } \\
\text { sapık 'süratli, çabuk, çevik, hızlı hareket eden' } \\
\text { sapkı '1. satır, 2. çapa' } \\
\text { sapkıla- 'satır ile doğramak, keskin bir şeyle dilmek, biçmek' } \\
\text { sapkın I 'haberci, ulak' } \\
\text { sapkın II 'beklenmedik anda yapılan baskın, ani saldırı' } \\
\text { sapkınsı I 'bk. sapkın I' } \\
\text { sapkınsı II 'baskına katılan asker' }\end{array}$ \\
\hline
\end{tabular}




\begin{tabular}{|c|c|}
\hline & $\begin{array}{l}\text { sapkır 'hızlı koşan, yüğrük, iyi koşan (at için)' } \\
\text { sapkıs '1. biçme makinesi, orak makinesi, 2. çapa, kazma; balta' } \\
\text { sapkısla- 'balta ile kesmek, keserle doğramak' } \\
\text { sapmala- 'büyük adımlarla koşmak, büyük adımlarla ilerlemek' } \\
\text { sapsan I '1. süratli, çabuk, çevik, hızlı hareket eden, 2. eli çabuk' } \\
\text { sapsanla- 'süratli hale getirmek, çevik hale getirmek, hızlandırmak, ecele } \\
\text { etmek' } \\
\text { sapsanlan- 'süratli olmak, hızlı olmak, çevik olmak' } \\
\text { sapsavla- 'huzursuzlanmak, rahatsız olmak, sakin olmamak' } \\
\text { sapst- '1. tırnaklamak, tırnak geçirmek; kazmak, 2. ön ayakları ile toprağ1 } \\
\text { tepmek (at için), 3. huzursuz olup çoşmak' } \\
\text { sapsın- '1. tırnaklanmak, tırnak geçirilmek, 2. kazılmak, 3. tepinmek (at } \\
\text { için)' } \\
\text { sapsış- '1. birlikte ya da karşllıklı tırnaklamak, tırnak geçirmek; kazmak, 2. } \\
\text { birlikte ön ayaklar ile tepmek, kazımak (at için)' } \\
\text { saptır- ' '1. sıçratarak yürütmek, sıçratarak ilerletmek; dörtnala koşturmak, } \\
\text { 2. fışkırarak akmak, püskürerek akmak' } \\
\text { saptır- II 'gerinerek hızlıca vurdurmak (yanağa, yüze), 2. sauna içerisinde } \\
\text { yaprak demeti ile vurdurmak, 3. kestirmek, biçtirmek, kırktırmak' } \\
\text { saptırıs- 'birlikte ya da karşıllklı̈ dörtnala at koşturmak' } \\
\text { saptırt- 'sıçratarak yürüttürmek, sıçratarak ilerlettirmek; dörtnala } \\
\text { koşturtmak' (Özşahin, 2017: 489-490, 497-498). }\end{array}$ \\
\hline Nogay Türkçesi & 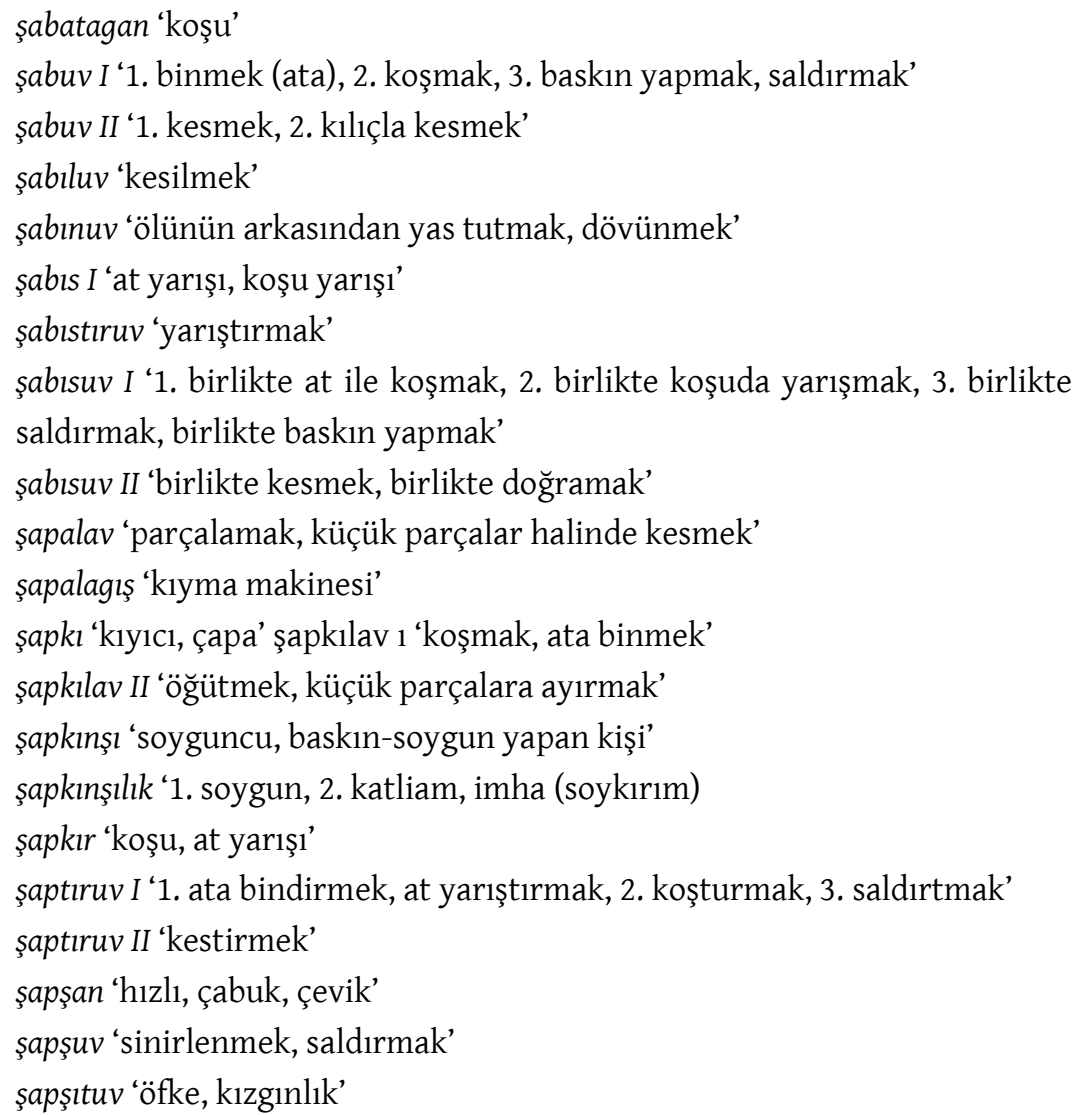 \\
\hline
\end{tabular}




\section{J(ఆ)}

\begin{tabular}{|c|c|}
\hline & ş̧apıldav ‘sıçramak, bir şeyle vurmak' (Kalmıkova, 1963: 400, 405). \\
\hline Şor Türkçesi & $\begin{array}{l}\text { şabık 'ot biçim, ot biçme' } \\
\text { şabış 'savaş, cenk, meydan savaşı, muharebe' } \\
\text { şap-II '1. çarpmak, vurmak, dövmek, 2. kuru ot tırpanlamak, kuru ot biçmek' } \\
\text { şapk1 'kapan, tuzak' (Tannagaşeva, 1995: 98-100). }\end{array}$ \\
\hline Halaç Türkçesi & $\begin{array}{l}\text { çap- '1. ata binmek, acele etmek, koşmak, 2. soymak, yağmalamak' } \\
\text { çapar 'haberci' } \\
\text { çapıştur- 'atı dörtnala koşturmak' (Doerfer, 1980: 98). }\end{array}$ \\
\hline Yakut Türkçesi & $\begin{array}{l}\text { sabaa '(el savurarak) vurmak' } \\
\text { saban- 'vurmak, kendine vurmak; kendini sallamak' } \\
\text { sabardaa 'işgal etmek, kapatmak (kendi başına bir yer)' } \\
\text { sabardaahın 'sabardaa fiilinden isim (işgal)' } \\
\text { sabat- 'sabardaa fiilinden ettirgen (işgal ettirmek)' } \\
\text { sabırğaa 'şaplak sesi çıkarmak' } \\
\text { sabırğat- 'hızlı ve güçlü şekilde vurmak, şaplak atmak' } \\
\text { sabırğatı 'sabığat- fiilinden isim (şaplak)' } \\
\text { sabırgaççı 'gürültülü şaplak' (Sleptsov, 1972: 307-308) } \\
\end{array}$ \\
\hline Çuvaş Türkçesi & 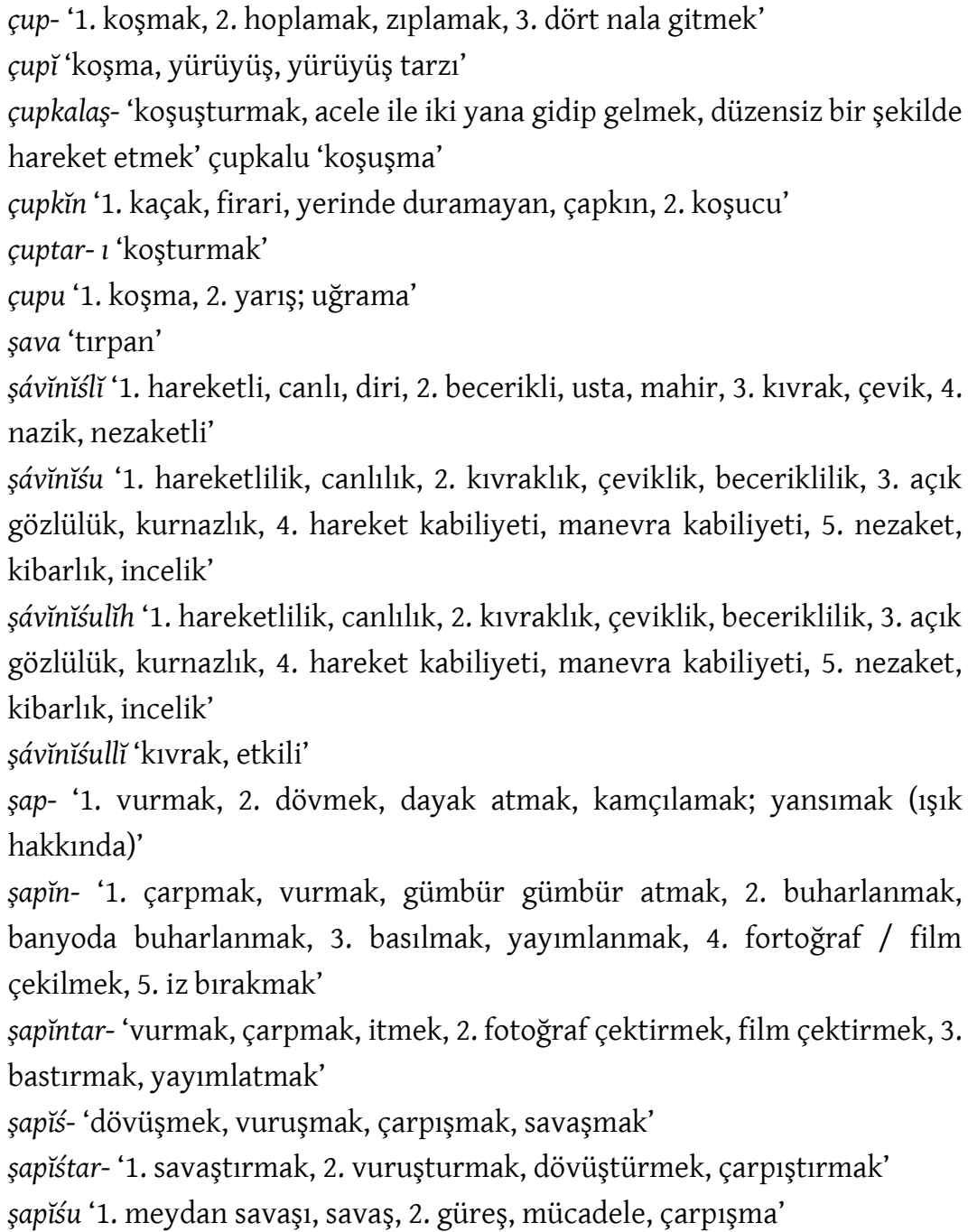 \\
\hline
\end{tabular}




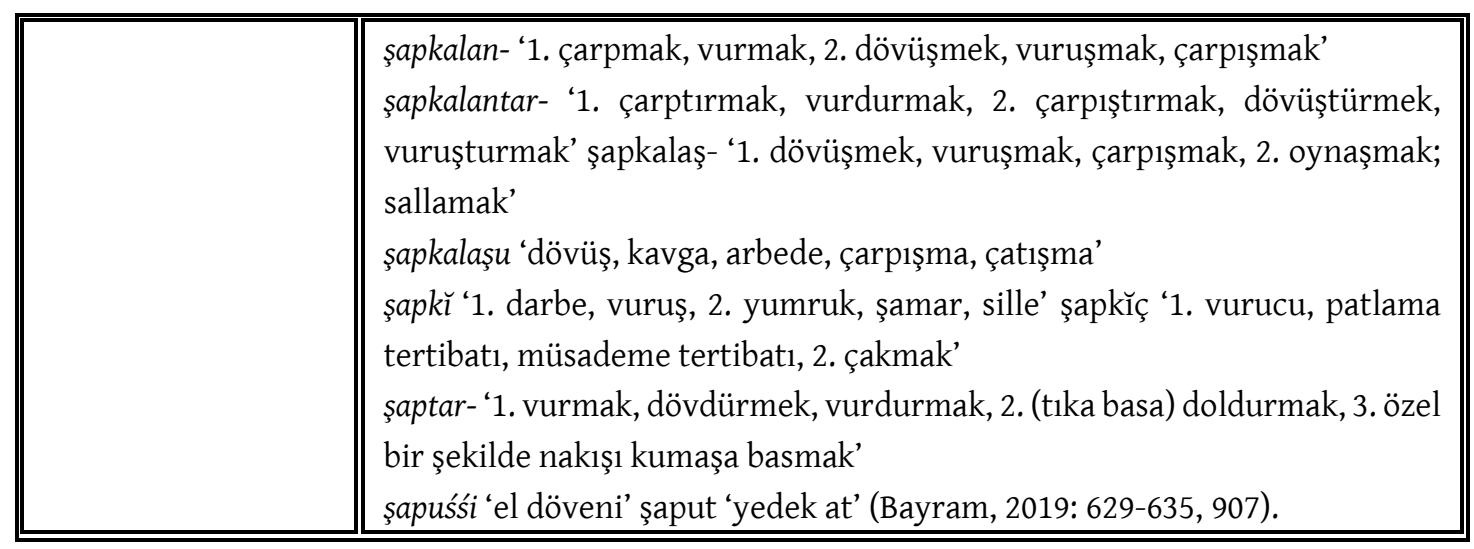

Tablo II, Çağdaş Türk Lehçeleri Tablosu

\section{Sonuç}

1. Söz konusu çap- fiili 'bir sıvıya ya da nispeten yumuşak bir yere vurunca çıkan ses' ile ilgili bir anlamla yansımadan türemiştir.

2. Hakkındaki ilk bilgilere DLT'de rastlanıyor olmasına karşın Uygur dönemi eserlerinde de çap- fiili türevleri ile birlikte kullanılmıştır. Ayrıca Japonca hariç- diğer bütün Altay dillerinde de bazı şekil değişiklikleri ile yaşadı̆̆ı anlaşılmaktadır.

3. Kelimenin Fince ve Macarcada (csap-) benzer şekillerde görülmesinin yanında Oset dilinde (cavd-), Soğdca ( $c b$-) ve Farsçada (çâpîdan) da benzer şekil ve anlamlarda kullanılmış olması kelimenin geniş coğrafyalara yayılmış olduğunu göstermektedir.

4. Tarihi ve çağdaş lehçelerimizdeki çap- fiilinden türemiş gövdelerin hepsi DLT'deki 'yüzmek; çamurla sıvamak; (boyun) vurmak, kesmek; kamçllamak; saldırmak' anlamlarından doğmuştur. 'Yüzmek' ve 'çamurla sıvamak' anlamlarından diğerlerine nispeten çok daha az kelime üretilmiştir.

5. Yine tarihi ve çağdaş lehçelerimize baktığımızda çap- fiili ile fiil gövdeleri oluştururken çatı eklerimizin (etken, edilgen, dönüşlü, işteş, ettirgen ve oldurgan olmak üzere) tüm varyasyonlarından faydalanıldığı görülmektedir.

6. Lehçelerimizde çap- fiilinin çab-, çop-, çup-, sap-, şap- gibi değişik ses değişimleriyle kullanıldı̆̆ı, türevlerinin de bu ses değişimlerine uygun şekillerde türetildiği görülmektedir. En dikkat çekici değişimler ise Özbek Türkçesi ve Çuvaş Türkçesinde yaşanmıştır. Özbek Türkçesinde fiil 'sürmek, sıvamak' anlamında çap- şeklinde kullanılırken 'koşmak ve kesmek' anlamlarında çop- 
şeklinde kullanılmaktadır. Yine Çuvaş Türkçesinde 'koşmak' anlamında çupşeklinde kullanılan fiil, 'vurmak' anlamında şap- şeklinde kullanılmaktadır. Bu da şekil değişikliğinin anlam ayırıyor olması açısından dikkat çekicidir.

7. Kaynaklarda başka dillerden Türkçeye geçtiği iddia edilen ya da kökeni ile ilgili bir fikir beyan edilmeyen bazı kelimelerin çap- fiilinden türediği anlaşılmaktadır: çabuk (çabucak, çarçabuk), çapa, çapak 'balık', çapla 'maden kazımak için kullanılan çelik kalem', çapı 'güveç, toprak tencere', çapık/çepik 'alkış', çaprak/şaprak 'eyer örtüsü', çaput 'eskimiş bez parçası, paçavra', çavuş, çepin 'küçük çapa', çevik.

8. Kaynaklarda çap- fiilinden türediği iddia edilen bazı kelimelerin ise çapfiilinden türemiş olma ihtimali düşüktür: çaba 'herhangi bir işi yapmak için ortaya konan güç, zorlu, sürekli çalışma, gayret', çapak 'göz pınarında ve kirpiklerde birikerek pihtılaşan veya kuruyan akıntı', çöp 'gübre, atık'.

9. Tarihi sürece baktığımızda çap- fiili ve türevleri, her geçen dönemde kullanım alanını ve anlam ağını genişleterek günümüz Türk lehçelerinde varlığını sürdürmektedir. Burada Türkiye Türkçesini çap- fiili ve türevlerinin kullanımı açısından diğer lehçelerden ayırmak gerekir. Türkiye Türkçesinde ağızlar hariç- çap- fiil kökünün tamamen unutulmuş olması ve bu lehçede kullanılan türevlerin bu köke bağlanmada zorluk çekilmesi, kökün inorganik bir /r/ türemesi ile çarp- şeklini almış olmasından ileri gelmektedir. Bu /r/türemesi ile birlikte anlam daralması da yaşamış olan fiil, aslen 'vurmak', mecazen 'çalmak' anlamlarıyla yaşamaya devam etmiştir. Bu kökten de tarihi süreçle ilgili olarak iki türev ortaya çıkmıştır: çarpı 'kaba sıva' ve çarpıntı 'kalbin hızlı ve sık vurması'.

Türkiye Türkçesi ve Anadolu Ağızlarında Kullanılan Türevler

Söz konusu çap- fiilinin ses yansımalı çap'tan türediği dikkate alınırsa gövdelerin hem isim kökü olan çap'tan hem de fiil kökü çap-'tan türeyebileceği göz önünde bulundurulmalıdır. Böylece türevlerin aldığı ekler fiilden isim yapan ekler olabileceği gibi isimden isim yapan ekler de olabilir.

\begin{tabular}{|c|c|c|}
\hline Kesin Türevler & Muhtemel Türevler* & Zayıf Türevler** \\
\hline çapar (eskimiş) ‘postacı, ulak’ & çabuk 'çabuk, hızlı' & $\begin{array}{l}\text { çaba 'herhangi bir işi yapmak } \\
\text { için ortaya konan güç, zorlu, } \\
\text { sürekli çalışma, gayret' }\end{array}$ \\
\hline (An. Ă̆g.) çapa çapa 'koşa koşa' & çabucak 'kısa sürede' & $\begin{array}{c}\text { çapak 'göz pınarında ve } \\
\text { kirpiklerde birikerek pıhtılaşan } \\
\text { veya kuruyan akıntı' }\end{array}$ \\
\hline
\end{tabular}




\begin{tabular}{|c|c|c|}
\hline $\begin{array}{c}\text { (An. Ă̆g.) çapcak, çapcık, } \\
\text { çapıçak, çapik, çapık 'çabucak' }\end{array}$ & çapa 'çapa, kazma, dirgen' & çöp 'gübre, atık' \\
\hline (An. Ăğ.) çapdır- 'koşturmak' & çapak 'balık' & \\
\hline $\begin{array}{l}\text { (An. Ağz.) çapını açmak } \\
\text { 'hızlandırmak' }\end{array}$ & $\begin{array}{l}\text { (An. Ağz.) çapı 'güveç, toprak } \\
\text { tencere' }\end{array}$ & \\
\hline $\begin{array}{l}\text { (An. Ağz.) çapkı 'bir şeyi } \\
\text { yağmalamak için yapılan } \\
\text { akın' }\end{array}$ & (An. Ăğ.) çapık/çepik 'alkış’ & \\
\hline $\begin{array}{l}\text { (An. Ağz.) çapkılamak 'akın } \\
\text { etmek' }\end{array}$ & $\begin{array}{l}\text { çapla 'maden kazımak için } \\
\text { kullanılan çelik kalem' }\end{array}$ & \\
\hline (An. Ağz.) çapkııı 'akıncı' & çaprak/şaprak 'eyer örtüsü’ & \\
\hline $\begin{array}{c}\text { çapkın 'geçici aşklar ve } \\
\text { ilişkiler peşinde koşan kimse, } \\
\text { hovarda; haylaz' }\end{array}$ & $\begin{array}{c}\text { çaput 'eskimiş bez parçası, } \\
\text { paçavra' }\end{array}$ & \\
\hline çapul 'yağma, talan, plaçka' & çarçabuk 'çabucak' & \\
\hline $\begin{array}{l}\text { çapulcu 'başkasının malını } \\
\text { alan, talan eden kimse, } \\
\text { talancı, yağmacı, plaçkacı' }\end{array}$ & çavuş 'askeri rütbe' & \\
\hline $\begin{array}{l}\text { çapulculuk 'çapulcunun } \\
\text { yaptığı iş veya davranış' }\end{array}$ & (An. Ağz.) çepin 'küçük çapa' & \\
\hline $\begin{array}{c}\text { çapullamak 'bir yeri soymak, } \\
\text { yağmalamak' }\end{array}$ & çevik 'hızlı, atik' & \\
\hline çapullama 'çapullamak işi' & & \\
\hline $\begin{array}{c}\text { çarp- 'hızla değmek, vurmak; } \\
\text { el çabukluğu ile çalmak, } \\
\text { dolandırarak elde etmek; } \\
\text { kurnazlıkla ele geçirmek; } \\
\text { (kalp) hızlı hızlı vurmak' }\end{array}$ & & \\
\hline \multicolumn{3}{|c|}{$\begin{array}{l}\text { *Muhtemel türevler, kaynaklarda geçip çap- fiilinden türediği belirtilen ve bizce de bu kökten } \\
\text { türediğine inanılan gövdelerdir. } \\
\text { ** Zayıf türevler, kaynaklarda çap- fiilinden türediği belirtilen ancak bizce bu kökten türeme } \\
\text { ihtimali olmayan gövdelerdir. }\end{array}$} \\
\hline
\end{tabular}

Tablo III, Türkiye Türkçesi ve Anadolu Ağızlarında kullanılan türevler için yorum tablosu

\section{Kisaltmalar}

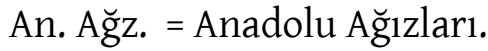

bk. = Bakınız.

Çev. = Çevirmen.

Dede $=$ Dede Korkut Hikâyeleri.

Dede E. = Dede Korku Hikâyeleri (Muharrem Ergin Neşri). 


\section{J(ఠ)}

DLT = Divanü Lugati't-Türk.

DS = Derleme Sözlüğü.

Enverî = Düsturname-i Enverî.

ET. $=$ Eski Türkçe.

Ev. = Evliya Çelebi Seyahatnamesi.

EWTS $=$ Etymologisches Wörterbuch der Turko-Tatarischen Sprachen.

Hurş. = Hurşid ü Ferahşad.

krş. = Karşılaştırınız.

Müslim = Ebamüslimname.

Sır. = Sırrü'l-Esrar ve Matlaü'l-Envar.

Solak = Solakzade Tarihi.

Ş.Galip = Şeyh Galip Divanı.

Şamil = Şamilü'l-Lüga.

Tennuri = Gülzar- Tennuri.

Tez. Lâ. = Tezkiretü'l-Evliya Tercümesi.

TiEM = Türk İslam Eserleri Müzesi.

TS = Türkçe Sözlük.

TTS = Tarama Sözlüğ̈̈ (1996).

Vasıf $=$ Vasıf Divanı

\section{Kaynakça}

Altaylı, S. (1994). Azerbaycan Türkçesi Sözlüğü I-II. Milli Eğitim Bakanlığı Yayınları. Arat, R. R. (1979). Kutadgu Bilig III, İndeks. Türk Kültürünü Araştırma Enstitüsü Yayınları.

Arat, R. R. (1991). Kutadgu Bilig II, Çeviri. Türk Dil Kurumu Yayınları.

Arat, R. R. (1992). Atabetü'l-Hakâyık. Türk Dil Kurumu Yayınları.

Arat, R. R. (1999). Kutadgu Bilig I, Metin. Türk Dil Kurumu Yayınları.

Arslan-Erol, H. (2014). Eski Türkçeden Eski Anadolu Türkçesine Anlam Değişmeleri. Türk Dil Kurumu Yayınları. 


\section{ग(ब)}

Ata, A. (1997). Kıssasü’l Enbiyâ (Peygamber Kıssaları) II, Dizin. Türk Dil Kurumu Yayınları.

Ata, A. (1998). Nehcü'l-Ferâdis, Uştmahlarnıng Açuk Yolı-Cennetlerin Açık Yolu III, DizinSözlük. Türk Dil Kurumu Yayınları.

Ata, A. (2013). Karahanl Türkçesinde İlk Kuran Tercümesi (Rylands Nüshası, GirişMetin-Notlar-Dizin). Türk Dil Kurumu Yayınları.

Atalay, B. (1945). Et-Tuhfetü'z-Zekiyye Fi'l-Lügati't-Türkiyye. Türk Dil Kurumu Yayınları.

Atalay, B. (1970). Abuşka Lugatı veya Çağatay Sözlüğü. Ayyıldız Matbaası.

Atalay, B. (1985). Divanü Lugat-it-Türk I-III. Türk Dil Kurumu Yayınları.

Atalay, B. (1986). Divanü Lugat-i-Türk Dizini IV, Endeks. Türk Dil Kurumu Yayınları.

Ayazlı, Ö. (2016). Eski Uygurca Din Dışı Metinlerin Karşılaştırmalı Söz Varlı̆̆ı. Türk Dil Kurumu Yayınları.

Bang, W. \& Arat, R. R. (1936). Oğuz Kağan Destanı. Burhaneddin Basımevi.

Baskakov, N. A. (1963). Nogayisko-Russkiyi Slovar. Gosudarstvennoye Izdatel'stvo Inostrannykh I Natsional'nykh Slovarey.

Baskakov, N. A. et al. (1974). Karaimsko-Russko-Polskiy Slovar. İzdatelstvo 'Ruskiy Jazık'.

Baskakov, N. A. et al. (1991). Gagauz Türkçesinin Sözlüğü. Çev. İ. Kaynak \& A. Mecit Doğru. Kültür Bakanlığı Yayınları.

Bayram, B. (2019). Çuvaş Türkçesi Sözlüğü. Türk Dil Kurumu Yayınları.

Borovkov, A. K. (1963). Leksika Sredneaziatskogo Tefsira XII-XIII vv. Akademiya Nauk SSSR (Institut Narodov Azii), Izdatel'stvo Vostoçnoy Literaturı.

Borovkov, A. K. (2002). Orta Asya'da Bulunmuş Kuran Tefsirinin Söz Varlı̆̆ı (XII-XIII. Yüzyıllar). Çev. H. İ. Usta \& E. Amanoğlu. Türk Dil Kurumu Yayınları.

Buran, A. (2013). Türkiye Türkçesi Ağızlarında -r-/-r Türemesi. In Gül, B. (Ed.), Bengü Beläk Ahmet Bican Ercilasun Armağanı (pp. 183-192). Türk Kültürünü Araştırma Enstitüsü Yayınları.

Büyük Türkçe Sözlük (2011). Türk Dil Kurumu Yayınları.

Caferoğlu, A. (1931). Kitâb Al-ídrâk Li-Lisân Al-Atrâk. Evkaf Matbaası.

Caferoğlu, A. (1993). Eski Uygur Türkçesi Sözlüğü. Enderun Kitabevi. 
Canpolat, M. (1995). Mecmuatü’n-Nezâir (Metin-Dizin-Tıpkıbasım). Türk Dil Kurumu Yayınları.

Clauson, Sir G. (1972). An Etymological Dictionary of Pre-Thirteenth-Century Turkish. Oxford University Press.

Çetin, E. (2019). Türkçe Çal- ve Çap- Fiilleri Üzerine Bir İnceleme. Çukurova Üniversitesi Türkoloji Araştırmaları Dergisi, 4(2), 375-390.

Demirci, Ü. Ö. \& Karslı, S. (2014). Kutb’un Husrev ü Şirin’i Dizin. Kesit Yayınları.

Demirci, Ü. Ö. (2016). Eski Türkçede Fiiller. Umuttepe Yayınları.

Dilçin, C. (1991). Süheyl ü Nevbahar, İnceleme-Metin-Sözlük. Atatürk Kültür Merkezi Yayınları.

Doerfer, G. \& Tezcan, S. (1980). Wörterbuch des Chaladsch (Dialekt von Charrab). Akadémiai Kiadó.

Doerfer, G. (1963). Türkische und mongolische Elemente im Neupersischen, unter besonderer Berücksichtigung älterer neupersischer Geschichtsquellen, vor allem der Mongolenund Timuridenszeit I. Franz Steiner Verlag.

Doerfer, G. (1965). Türkische und mongolische Elemente im Neupersischen, unter besonderer Berücksichtigung älterer neupersischer Geschichtsquellen, vor allem der Mongolenund Timuridenszeit II. Franz Steiner Verlag.

Doerfer, G. (1967). Türkische und mongolische Elemente im Neupersischen, unter besonderer Berücksichtigung älterer neupersischer Geschichtsquellen, vor allem der Mongolenund Timuridenszeit III. Franz Steiner Verlag.

Doerfer, G. (1975). Türkische und mongolische Elemente im Neupersischen, unter besonderer Berücksichtigung älterer neupersischer Geschichtsquellen, vor allem der Mongolenund Timuridenszeit IV. Franz Steiner Verlag.

Eckmann, J. (2014). Nehcü'l-Ferâdis, Uştmahlarning Açuk Yolı-Cennetlerin Açık Yolu. Türk Dil Kurumu Yayınları.

Eren, H. (1999). Türk Dilinin Etimolojik Sözlüğü. Bulak Neşriyat.

Gökyay, O. Ş. (2007). Dedem Korkudun Kitabı. Kabalcı Yayınevi.

Gülensoy, T. (2007). Türkiye Türkçesindeki Türkçe Sözcüklerin Köken Bilgisi Sözlüğü III. Türk Dil Kurumu Yayınları.

Hacieminoğlu, N. (2000). Kutb’un Husrev ü Şirin'i ve Dil Hususiyetleri. Türk Dil Kurumu Yayınları. 


\section{0}

İzbudak, V. (1965). El-İdrâk Haşiyesi. Devlet Basımevi.

Kanar, M. (2011). Eski Anadolu Türkçesi Sözlüğü. Say Yayınları.

Karamanlıoğlu, A. F. (1989). Seyf-i Sarâyî Gülistan Tercümesi (Kitâb Gülistan bi't-Türkî). Türk Dil Kurumu Yayınları.

Karasoy, Y. (1998). Şiban Han Divanı (İnceleme-Metin-Dizin-Tipkıbasım). Türk Dil Kurumu Yayınları.

Kayasandık, A. (2018). Türkiye Türkçesinde Ölen Fiiller. Teke Uluslararası Türkçe Edebiyat Kültür Eğitim Dergisi, 7(1), 105-125.

Koç, K. et al. (2003). Kazak Türkçesi Türkiye Türkçesi Sözlüğü. Akçağ Yayınları.

Küçük, M. (2014). Eski Anadolu Türkçesi Dönemine Ait Satır Arası Illk Kuran Tercümesi (Giriş-İnceleme-Metin-Dizin). Türk Dil Kurumu Yayınları.

Kültüral, Z. \& Beyreli, L. (1999). Şerîfi Şehnâme Çevirisi I-IV. Türk Dil Kurumu Yayınları.

Nadelyayev, V. M. et al. (1969). Drevnetyurkskiy Slovar'. İzdatel'stvo "Nauka" Leningradskoye Otdeleniye Leningrad.

Naskali, E. G. \& Duranlı, M. (1999). Altayca-Türkçe Sözlük. Türk Dil Kurumu Yayınları.

Naskali, E. G. et al. (2007). Hakasça-Türkçe Sözlük. Türk Dil Kurumu Yayınları.

Necip, E. N. (1995). Yeni Uygur Türkçesi Sözlüğü. Çev. İ. Kurban. Türk Dil Kurumu Yayınları.

Ölmez, Z. K. (1996). Şecere-i Terâkime (Türkmenlerin Soykütüğü). Simurg Yayınları.

Öner, M. (2009). Kazan-Tatar Türkçesi Sözlüğü. Türk Dil Kurumu Yayınları.

Öner, M. (2013). Bugünkü Kıpçak Türkçesi. Türk Dil Kurumu Yayınları.

Özşahin, M. (2017). Başkurt Türkçesi Sözlüğü. Türk Dil Kurumu Yayınları.

Pekacar, Çetin (2011). Kumuk Türkçesi Sözlüğü. Türk Dil Kurumu Yayınları.

Räsänen, M. (1969). Versuch eines etymologischen Wörterbuchs der Türksprachen. Lexica Societatis Fenno-Ugricae.

Sleptsov, P. A. (1972). Yakutsko-Russkiy Slovar. Izdatel'stvo Sovetskaya Entsiklopediya.

Starostin, S. A. et al. (2003). An Etymological Dictionary of the Altaic Languages I-III. Brill. 


\section{ग(৫)}

Şahin, H. (2003). Eski Anadolu Türkçesi. Akçağ Yayınları.

Şeyh Süleyman Efendi Buhârî (1298/ M. 1882). Lügat-i Çağatay ve Türkî-i Osmanî. Mihran Matbaası.

Talat, T. et al. (1995). Türkmence-Türkçe Sözlük. Simurg Yayınları.

Tannagaşeva, N. et al. (1995). Şor Sözlüğü. Çukurova Üniversitesi Basımevi.

Tavkul, U. (2000). Karaçay-Malkar Türkçesi Sözlüğü. Türk Dil Kurumu Yayınları.

Tezcan, S.(1974). Das uiguische Insadi-Sutra. Berliner Turfantexte 3. Akademie Verlag.

Tietze, Andreas (2002). Tarihi ve Etimolojik Türkiye Türkçesi Lügatı I: A-E. Simurg Yayınları.

Toparl1, R. (1992). İrşâdü'l-Mülûk ve’s-Selâtîn. Türk Dil Kurumu Yayınları.

Toparl1, R. (2018) Ed-Dürretü'l-Mudiyye Fi'l-Lügati't-Türkiyye. Türk Dil Kurumu Yayınları.

Toparlı, R. et al. (2014). Kıpçak Türkçesi Sözlüğü. Türk Dil Kurumu Yayınları.

Türkiye'de Halk Ağzından Derleme Sözlüğ̈̈ I-XII (1993). 2. Baskı. Türk Dil Kurumu Yayınları.

Uğurlu, M. (1987). Munyetü’l Guzât. Kültür ve Turizm Bakanlı̆̆ı Yayınları.

Usta, H. İ. (1989). XIII. Yüzyıl Doğu Türkçesiyle Yazılmış Anonim Kuran Tefsirinin Söz ve Şekil Varlığı. Ankara Üniversitesi, Sosyal Bilimler Enstitüsü. (Yayımlanmamış Yüksek Lisans Tezi)

Ünlü, S. (2004). Karahanlı Türkçesi Satır Arası Kuran Tercümesi (Tiem 73), Giriş-MetinInceleme-Analitik Dizin. Hacettepe Üniversitesi, Sosyal Bilimler Enstitüsü. (Yayımlanmamış Doktora Tezi)

Ünlü, S. (2012). Harezm-Altınordu Türkçesi Sözlüğü. Eğitim Yayınevi.

Ünlü, S. (2013). Çağatay Türkçesi Sözlüğü. Eğitim Yayınevi.

Üşenmez, E. (2010). Karahanlı Türkçesinin Sözlüğü. Doğu Kitabevi.

Üşenmez, E. et al. (2016). Özbekçe-Türkçe Sözlük. Türk Dünyası Vakfı Yayınları.

Vambery, H. (1878). Etymologisches Wörterbuch der Turko-Tatarischen Sprachen. F.A. Brockhaus.

XIII. Yüzyıldan Beri Türkiye Türkçesiyle Yazılmış Kitaplardan Toplanan Tanıklarıyla Tarama Sözlüğ̈̈ I-VIII (1996). 2. Baskı. Türk Dil Kurumu Yayınları. 


\section{J(ఠ)}

Yudahin, K. K. (1998). Kırgız Sözlüğü I-II. Çev. A. Taymas. Türk Dil Kurumu Yayınları. Yüce, N. (2014). Zemahşerî: Mukaddimet'ül Edeb. Türk Dil Kurumu Yayınları.

Zieme, P. \& Molnar, A. (1989). Ein weiterer uigurischer Erntesegen. Altorientalische Forschungen, 16, 140-152.

Zieme, P. (1975). Ein uigurischer Erntesegen. Altorientalische Forschungen, 3, 109143.

Zülfikar, H. (1995). Türkçede Ses Yansımalı Kelimeler. Türk Dil Kurumu Yayınları. 